\title{
Deep-sea pre-glacial to glacial sedimentation in the Weddell Sea and southern Scotia Sea from a cross-basin seismic transect
}

\author{
Ansa Lindeque ${ }^{\mathrm{a}, *}$, Yasmina M. Martos ${ }^{\mathrm{b}}$, Karsten Gohl ${ }^{\mathrm{c}}$, Andrés Maldonado ${ }^{\mathrm{b}}$ \\ a Alfred Wegener Institute for Polar and Marine Research, Am Alten Hafen 26, 27568 Bremerhaven, Germany. Now at TGS, Millbank House, 171-185 Ewell Road, Surbiton, \\ Surrey, KT6 6AP, UK \\ b Instituto Andaluz de Ciencias de la Tierra, CSIC/Universidad Granada, 18100 Armilla, Granada, Spain \\ c Alfred Wegener Institute for Polar and Marine Research, Am Alten Hafen 26, 27568 Bremerhaven, Germany
}

\section{A R T I C L E I N F O}

\section{Article history:}

Received 3 March 2012

Received in revised form 22 October 2012

Accepted 4 November 2012

Available online 27 November 2012

Communicated by D.J.W. Piper

\section{Keywords:}

Antarctica

Weddell Gyre

Ice sheet expansion

Seismic reflection data

Seismic stratigraphy

\begin{abstract}
A B S T R A C T
Identification of the pre-glacial, transitional and full glacial components in the deep-sea sedimentary record is necessary to understand the ice sheet development of Antarctica and to build circum-Antarctic sediment thickness grids for palaeotopography/-bathymetry reconstructions, which constrain palaeoclimate models. A $~ 3300 \mathrm{~km}$ long Weddell Sea to Scotia Sea multichannel seismic reflection data transect was constructed to define the first basin-wide seismostratigraphy and to identify the pre-glacial to glacial components. Seven main seismic units were mapped: Of these, WS-S1, WS-S2 and WS-S3 comprise the inferred Cretaceous-Palaeocene pre-glacial regime ( $>27 \mathrm{Ma}$ in our age model), WS-S4 the Eocene-Oligocene transitional regime (27-11 Ma) and WS-S5, WS-S6, WS-S7 the Miocene-Pleistocene full glacial climate regime (11-1 Ma). Sparse borehole data from ODP Leg 113 and SHALDRIL constrain the ages of the upper three seismic units and seafloor spreading magnetic anomalies compiled from literature constrain the basement ages in the presented age model. The new horizons and stratigraphy often contradict local studies and show an increase in age from southeast to the northwest. The up to $1130 \mathrm{~m}$ thick pre-glacial seismic units form a mound in the central Weddell Sea basin and in conjunction with the eroded flank geometry, allow the interpretation of a Cretaceous proto-Weddell Gyre bottom current. The base reflector of the transitional seismic unit has a model age of 26.6-15.5 Ma from southeast to northwest, suggesting similar southeast to northwest initial ice sheet propagation to the outer shelf. We interpret an Eocene East Antarctic Ice Sheet expansion, Oligocene grounding of the West Antarctic Ice Sheet and Early Miocene grounding of the Antarctic Peninsula Ice Sheet. The transitional regime sedimentation rates in the central and northwestern Weddell Sea $(6-10 \mathrm{~cm} /$ $\mathrm{ky})$ are higher than in the pre-glacial $(1-3 \mathrm{~cm} / \mathrm{ky})$ and full glacial regimes $(4-8 \mathrm{~cm} / \mathrm{ky})$. The pre-glacial to glacial rates are highest in the Jane- and Powell Basins (10-12 cm/ky). Total sediment volume in the Weddell Sea deep-sea basin is estimated at $3.3-3.9 \times 10^{6} \mathrm{~km}^{3}$.
\end{abstract}

(c) 2012 Elsevier B.V. All rights reserved.

\section{Introduction}

Deep-sea sediment thicknesses, distribution patterns and deposition characteristics reveal the erosional, transport and deposition processes that were active during Antarctica's transition from a warm, pre-glacial to a cold, glacial climate. The geometry, distribution and thickness of sediment sequences produced by these processes can provide insight into the ice sheet development and palaeocirculation of the Weddell Sea. Additionally, sediment thickness grids are needed for palaeotopography (Lythe et al., 2001; Le Brocq et al., 2010; Wilson et al., 2011) and palaeobathymetry (Brown et al., 2006; Hayes et al., 2009) reconstructions at epochs with similar or higher atmospheric

\footnotetext{
* Corresponding author. Tel.: +447443833836.

E-mail addresses: ansa.lindeque@tgs.com (A. Lindeque), yasmartos@ugr.es (Y.M. Martos), karsten.gohl@awi.de (K. Gohl), amaldona@ugr.es (A. Maldonado).
}

$\mathrm{pCO}_{2}$ than today, like the Eocene, Miocene, Pliocene and Pleistocene (Pagani et al., 2005; Tripati et al., 2009, 2011). These palaeo-surface reconstructions provide boundary conditions for palaeoclimate models (e.g. Pollard and DeConto, 2009), which focus on predicting ice sheet behaviour under continued increase of $\mathrm{pCO}_{2}$ levels.

Identification of these pre-glacial to glacial components in the deepsea seismic sedimentary records is largely unresolved for the Weddell Sea basin and cross-regional stratigraphic grids for the West Antarctic margin are still absent. As a result, sediment thickness is largely omitted in palaeobathymetry reconstructions (e.g. Brown et al., 2006), or if considered, contain data from the 1970's (Hayes and La Brecque, 1991; Hayes et al., 2009) and few data points (Laske and Masters, 1997), which distort the grids. Tracing continuous horizons over large $(>500 \mathrm{~km})$ distances in seamless seismic data are thus needed to develop a basin-wide stratigraphy, identify the pre-glacial to glacial components in the deep-sea sedimentary record and estimate sediment thickness and volume. 


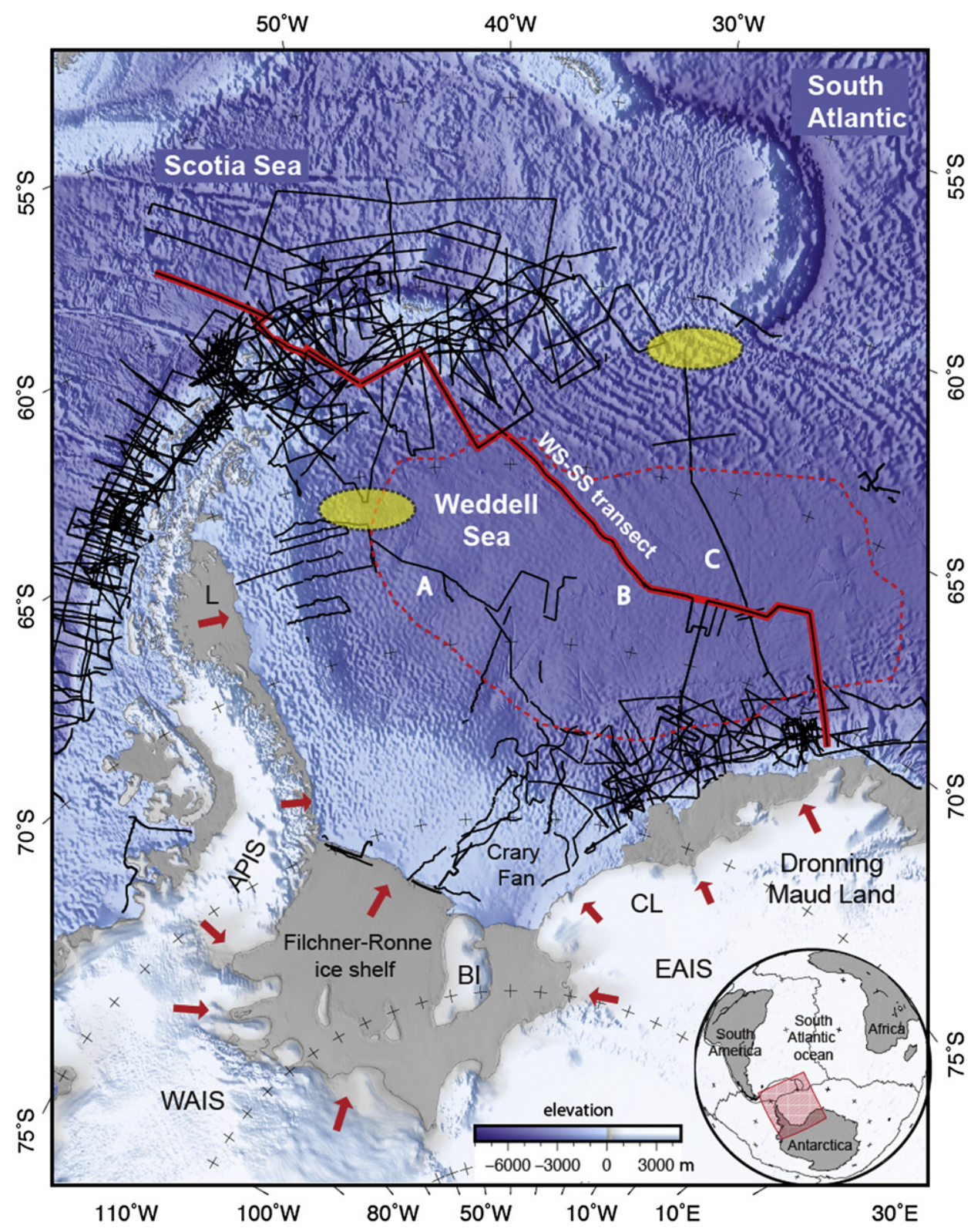

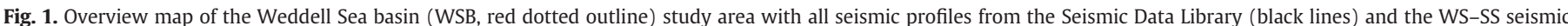

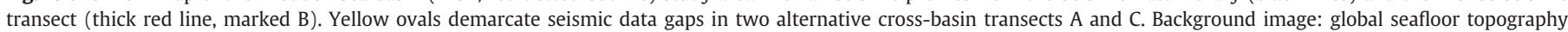

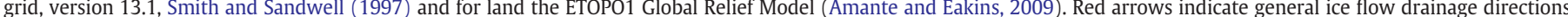

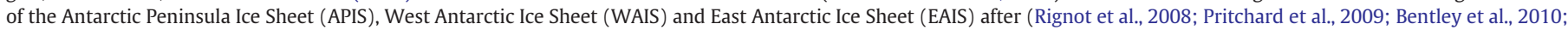
Jamieson et al., 2010). L-Larsen ice shelf, BI-Berkner Island, CL-Coats Land. Globe insert: plate boundaries and study area (red square).

Notes to Table 1

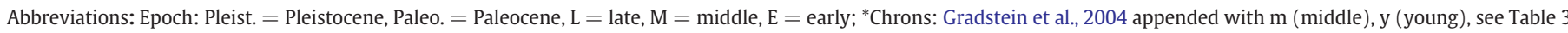

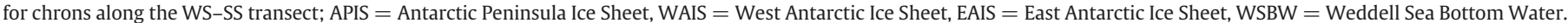

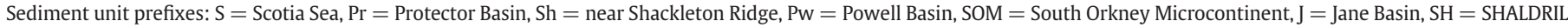
II James Ross Basin, $\mathrm{WD}=$ northwestern Weddell Sea, $\mathrm{W}=$ southeastern Weddell Sea; $\mathrm{pCO}_{2} \mathrm{ppm}=$ partial pressure atmospheric $\mathrm{CO}_{2}$ in parts per million.

References: ${ }^{1}$ Anderson, 2006; ${ }^{2}$ Smith \& Anderson, $2010{ }^{3}$ Busetti et al, 2000; ${ }^{4}$ Maldonado et al, 2006; ${ }^{5}$ Larter \& Barker, 1989; ${ }^{6}$ Larter \& Cunningham, 1993; ${ }^{7}$ Barker et al. 1988;

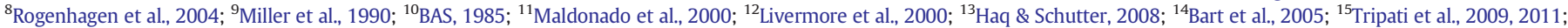

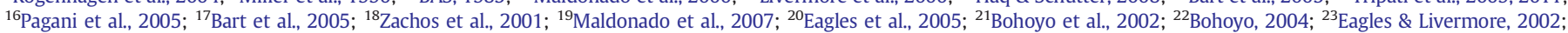

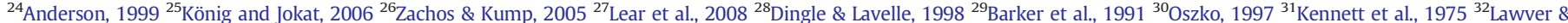

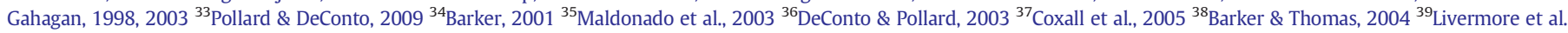

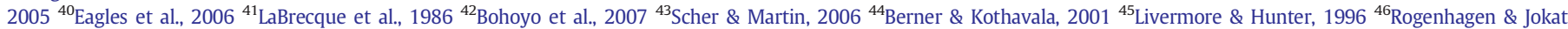

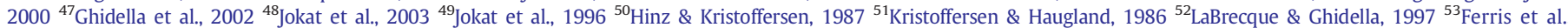

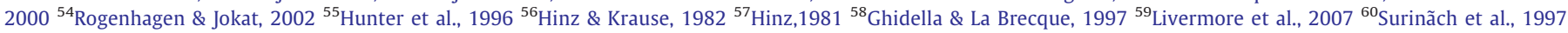
${ }^{61}$ Galindo-Zaldívar et al., 2006. 
Table 1

Deposition of seismic stratigraphic units in the Weddell and Scotia Seas during changes in tectonics, glaciation, climate and ocean circulation.

\begin{tabular}{|c|c|c|c|c|c|c|c|c|}
\hline Epocl & & $\begin{array}{l}\text { Age } \\
(\mathrm{Ma})\end{array}$ & Chron* & $\begin{array}{l}\text { Seismic stratigraphic units, } \\
\text { prefix indicates basin }\end{array}$ & $\begin{array}{l}\text { Changes in tectonics, glaciation, sea level, climate and oceancirculation } \\
\text { from literature }\end{array}$ & & & \\
\hline Pleist & & 0.0 & C1y & SH1 $(2.4-1.6 \mathrm{Ma})^{1,2}$ & Multiple grounding and retreat cycles of the APIS, WAIS and EAIS ${ }^{1,2,4,5,6}$ & & & \\
\hline & & & & SOM-A $(\text { ODP695,6,7) })^{3}$ & Spreading in eastern Scotia Sea ends $(\mathrm{C} 20,1.96 \mathrm{Ma})^{10}$ & & & \\
\hline & $\mathrm{L}$ & 2.6 & C2Ay & S1,Pr1,Sh1,Pw1,J1,WD1 ${ }^{4}$ & Intensified deep-water production, sheeted facies amd contourite deposits ${ }^{2,4,11}$ & & $\approx$ & \\
\hline 䒕 & & & & reflector a $(3.8-3.5 \mathrm{Ma})^{4}$ & Spreading in central Scotia Sea ends (C2A, $3.3 \mathrm{Ma})^{10,12}$ & & E & \\
\hline$\stackrel{\mathscr{O}}{=}$ & $\mathrm{E}$ & 3.6 & C2Ary & S1-S3 progradation ${ }^{5,6}$ & Major sea level decrease $(\mathrm{Za} 2)^{4,13}$ & & 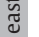 & \\
\hline & & & & SH2 (5.5-2.4 Ma) $)^{1,2}$ & Grounding cycles of APIS on the continental shelf more frequent ${ }^{2,5,7,14}$ & & & \\
\hline & $\mathrm{L}$ & 5.3 & C3ry & SOM-B (ODP695,6,7, Hz2) & $\mathrm{pCO}_{2}$ fluctuates $(200-400 \mathrm{ppm}, 12-0.01 \mathrm{Ma})^{15,16}$ & & & \\
\hline & & & & & Peninsula Pacific margin ridge-trench collisions ${ }^{5,6}$ sea level increase $\left(6.3 \mathrm{Ma}\right.$, Tor3/Me1) ${ }^{13}$ & & & \\
\hline & & & & S4-S6 (6 Ma $)^{5}$ & Spreading in eastern Scotia sea starts $(\mathrm{C} 4 \mathrm{n} .10,7.6 \mathrm{Ma})^{10}$ & & $\bar{\Xi}$ & \\
\hline & & & & & Uplift at South Scotia Fracture Zone and Antarctic Peninsula $\sim 8$ Ma ago ${ }^{59}$ & & & \\
\hline & & & & S2,Pr2,Sh2,Pw2,J2,WD2 ${ }^{4}$ & High WSBW activity, expanding WAIS4,11 APIS grounding cycles (7.94-5.12 Ma) ${ }^{17}$ & & & \\
\hline & & & & SH3 $(8.2-5.5 \mathrm{Ma})^{1,2}$ & Northward expansion of APIS (S4, S3), relatively thin sheet or small ice caps ${ }^{1,2}$ & & & \\
\hline & & & & & Grounding cycles of EAIS and WAIS on the continental shelf ${ }^{2,4,18}$ & & & \\
\hline & & & & & Spreading in western Scotia Sea ends (C5n.2m, $10.5 \mathrm{Ma})^{19}$ & & & \\
\hline & & & & reflector $\left(68-64 \mathrm{Ma}^{4,7}\right.$ & Spreading in central Scotia Sea ends $(\mathrm{C} 5 \mathrm{n} .20,10.95 \mathrm{Ma})^{20}$ & & & \\
\hline$\Xi$ & & & & Feriector C (0.0-0.4 ivid) & Initial incursions of Weddell Sea Bottom Water (WSBW) into Scotia Sea ${ }^{4}$ & & & مُ \\
\hline .0 .0 & M & 11.6 & C5r.3ry & W5 (12 Ma, ODP692,3) & Permanent WAIS, bringing terrigenous sediments to margin ${ }^{1,2}$ & & & \\
\hline & & & & $\mathrm{S} 3, \mathrm{Pr} 3, \mathrm{Sh} 3, \mathrm{Pw} 3, \mathrm{~J} 3, \mathrm{WD}^{4}$ & Miocene glaciation (Mi4), a lowering of sea level (Ser3) and permanent EAIS ${ }^{4,13,18}$ & & & the \\
\hline & & & & reflector b $(12.6-12.1 \mathrm{Ma})^{7,4}$ & Mid-Miocene climate optimum (16-15 Ma) and global temperature decrease $\sim 8^{\circ} \mathrm{C}^{13,18}$ & & & \\
\hline & & & & SH4 (13.8-8.2 Ma) $)^{1,2}$ & Spreading in Jane Basin ends (C5ADm, $14.4 \mathrm{Ma})^{21,22}$ & & & \\
\hline & & & & $\operatorname{Pr} 4, \mathrm{~J} 4(14.1-12.1 \mathrm{Ma})^{4}$ & Early expansions of APIS onto the continental shelf in the south ${ }^{2}$ & & 이 & \\
\hline & & & & S4 (17.6-12.6 Ma $)^{4}$ & Bottom water circulation between Scotia Sea and Weddell Sea, WD4 drifts ${ }^{4}$ & & $\underbrace{y}$ & \\
\hline & E & 16.0 & C5Cn.1ny & $\operatorname{Pr} 5, J 5(17.6-12.6 \mathrm{Ma})^{4}$ & Spreading in Scan Basin ends $(\mathrm{C} 5 \mathrm{Cn} .3 \mathrm{~m}, 16.6 \mathrm{Ma})^{21}$ & & 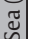 & \\
\hline & & & & Pw4,WD4 (18.5-12.6 Ma) ${ }^{4}$ & Spreading in Jane Basin and Scan basin starts (C5Dm, 17.6 Ma) ${ }^{21,22}$ & & & \\
\hline & & & & Sh4 (19.8-12.6 Ma) $)^{4}$ & $\mathrm{pCO}_{2}$ fluctuates (300 to $\left.400 \mathrm{ppm}, 20-12 \mathrm{Ma}\right)^{15}$ & & $n$ & ? \\
\hline & & & & S5 $(20.7-17.6 \mathrm{Ma})^{4}$ & Spreading in Weddell Sea $(\mathrm{C} 6 \mathrm{~m}, 19.2 \mathrm{Ma})^{21}$ and Powell Basin ends $(\mathrm{C} 6 \mathrm{AAo}, 21.1 \mathrm{Ma})^{23}$ & & & ? \\
\hline & $\mathrm{L}$ & 23.0 & C6Cn.2ry & WD5 (20.5-18.5 Ma) ${ }^{4}$ & EAIS fully developed to shelf edge $\mathrm{e}^{2,24-28} \mathrm{Mi}-1$ Glaciation, warming $5-6^{\circ} \mathrm{C}^{18}$ & & ( & \\
\hline & & & & $\operatorname{Sh} 5(28.0-19.0 \mathrm{Ma})^{4}$ & $\mathrm{pCO}_{2}$ increase $(\sim 400-930 \mathrm{ppm}, 28-25 \mathrm{Ma})$ rapid decrease $(\sim 930-400 \mathrm{ppm}, 25-23 \mathrm{Ma})^{16}$ & & & \\
\hline & & & & SOM-C (ODP695,6,7, Hz1) $)^{3,7}$ & Central Scotia Sea spreading starts $(\mathrm{C} 8 \mathrm{n} .20,26.1 \mathrm{Ma})^{20}$ & & 它 & \\
\hline & $\mathrm{E}$ & 28.4 & C10n.1ry & & $\mathrm{pCO}_{2}$ decrease $(1800-400 \mathrm{ppm}, 33-28 \mathrm{Ma})^{16}$ sealevel decrease by $\sim 100 \mathrm{~m}^{13}$ & & & \\
\hline$\cong$ & & & & & Earliest observed glacial event on the Antarctic Peninsula $(29.8 \mathrm{Ma})^{28}$ & & & \\
\hline$\breve{\Xi}$ & & & & & Opening of the Powell Basin starts (C11n.1o, 29.7 Ma) $)^{22,25,60}$ & & & বे \\
\hline .000 & & & & Pw5 (32.0-18.0 Ma) ${ }^{4}$ & Opening of the Protector Basin $(33.7-30.2 \mathrm{Ma})^{20,21,23}$ or $(17.4-13.8 \mathrm{Ma})^{61}$ & & & $\cong$ \\
\hline & & & & & Seafloor spreading in western Scotia Sea starts (C12m, $30.9 \mathrm{Ma})^{19,20,29}$ & & & \\
\hline & & & & & EAIS \& WAIS formation $(33-31 \mathrm{Ma})^{9,30,31,32}$ & & & \\
\hline & & & & & Onset of the Antarctic Circumpolar Current (ACC) $)^{4,29,32,33}$ & & & \\
\hline & & & & & Abrupt Eocene-Oligocene (ca. $33 \mathrm{Ma}$ ) cooling ${ }^{18,33,34}$ clockwise gyre in Scotia Sea ${ }^{35}$ & & & \\
\hline & $\mathrm{L}$ & 33.8 & C13ry & W4 (35 Ma, ODP692,3) & $\mathrm{pCO}_{2}$ decline $(1750-700 \mathrm{ppm}, 38-33 \mathrm{Ma})$, temp $\sim 4^{\circ} \mathrm{C}$ lower, orbital cycle changes ${ }^{33,36-39}$ & & & \\
\hline & & & & & Spreading in Dove Basin ends (C15y, $34.7 \mathrm{Ma})^{40}$ & & & \\
\hline & & & & & $\mathrm{pCO}_{2}$ increase $(750-1800 \mathrm{ppm}, 35-33 \mathrm{Ma})^{16}$ & & & \\
\hline & & & & SH5 (37-32 Ma) ${ }^{1,2}$ & Initial continental/alpine glaciation on the Peninsula $(49-32 \mathrm{Ma})^{2}$ & & & \\
\hline & & & & & Oi-1 glaciation ${ }^{18}$ small ephemiral ice sheets in west Antarctica, EAIS expansion $7,34,41$ & & & 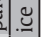 \\
\hline ฮूँ & & & & & Drake Passage fully open, SAM - Antarctic Peninsula separation complete ${ }^{29,39,42}$ & & & 눌 \\
\hline î & M & 37.2 & C17n.1ry & & Penetration of Pacific water through Drake Passage ${ }^{43}$ & & 켸 &.$\Xi$ \\
\hline & & & & & Opening of Dove Basin starts (C18n.2o, $39.4 \mathrm{Ma})^{40}$ & & 힌 & वे \\
\hline & & & & & $\mathrm{pCO}_{2}$ increase (800 to $\left.1800 \mathrm{ppm}, 55-42 \mathrm{Ma}\right)^{44}$ & & 范 & \\
\hline & E & 48.6 & C22ny & & Complete change in deep ocean circulation, Antarctic Bottom Water forms (AABW) ${ }^{4}$ & & चै & \\
\hline & & & & & Ridge-trench collisions on pacific margin of Peninsula starts $(50 \mathrm{Ma})^{5}$ & & 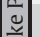 & \\
\hline & $\mathrm{L}$ & 55.8 & C24rm & & Drake Passage and Weddell Sea continues to open ${ }^{32,39,40}$ & & | & \\
\hline$\frac{\sqrt{n}}{2}$ & $\mathrm{E}$ & 61.7 & C27ny & & Shallow gateways, watermass exchange between Weddell and Scotia Seas ${ }^{32,39,40}$ & & & \\
\hline & L & 65.5 & C29rm & & Falkland Plateau clearing the tip of Africa, opening of Drake Passage starts ${ }^{25}$ & & & \\
\hline & & & & & Herringbone pattern anomalies form ${ }^{45,46,47}$ & & & \\
\hline & & & & & Spreading in Weddell Sea changes to WNW-ESE ${ }^{45,46,47}$ & & & \\
\hline & & 84.0 & C34ny & & $\mathrm{pCO}_{2}$ decrease $(>1800 \text { to } 800 \mathrm{ppm}, 145-56 \mathrm{Ma})^{44}$ & & & \\
\hline בై & $\mathrm{E}$ & 99.6 & $\mathrm{C} 34 \mathrm{~nm}$ & & Opening of South Atlantic Ocean complete, (AFR-ANT seperated) ${ }^{48}$ & & & \\
\hline 苂 & & & & W3 (114 Ma, ODP692,3) ${ }^{8}$ & Andenes Plateau ${ }^{49}$ Weddell Sea rift ${ }^{50}$ Polarstern Bank ${ }^{9}$ Orion magnetic anomaly ${ }^{41,51,52,53}$ & & & \\
\hline$\Xi$ & & & & W2 (118 Ma, ODP692,3) ${ }^{8}$ & Spreading in Weddell Sea now NNE-SSW and Anomaly-T forms ${ }^{52,54}$ & & & \\
\hline & & 124.6 & M0ry & W1.5 (136 Ma, ODP692,3) & Indian and South Atlantic oceans broaden, but gateways still closed ${ }^{25}$ & & & \\
\hline & & & & W3 $(138-125 \mathrm{Ma})^{9}$ & Shear margin becomes transpressional ${ }^{45}$ & & & \\
\hline & & & & & First oceanic crust in Weddell Sea (M17, $142 \mathrm{Ma})^{25}$ & & & \\
\hline & $\mathrm{L}$ & 145.9 & M19ry & & Explora Escarpment, Explora wedge and Explora Anomaly form ${ }^{25,50,55,56,57}$ & & & \\
\hline$\overline{\tilde{\widetilde{c}}}$ & & & & W1 (160-145 Ma) $)^{8,9}$ & $\mathrm{~N}-\mathrm{S}$ extention and stretching in front Dronning Maud Land, no seafloor yet ${ }^{25,48,58}$ & & & \\
\hline$\Xi$ & & 154.9 & M25Ary & & South America (SAM) - southern Africa (AFR) separates from Antarctica (ANT) $25,48,49$ & & & \\
\hline
\end{tabular}


Previous seismic reflection studies presented seismostratigraphy models for the southern Scotia Sea (e.g. Maldonado et al., 1998, 2003, 2005; Fig. 1), the Antarctic Peninsula (e.g. Larter and Barker, 1989; Rebesco and Camerlenghi, 2008; Smith and Anderson, 2010), the Jane and Powell Basins in the northwestern Weddell Sea (e.g. Coren et al., 1997; Bohoyo et al., 2002; Bohoyo, 2004; Fig. 1), and the southeastern Weddell Sea basin (Hinz and Kristoffersen, 1987; Miller et al., 1990; Rogenhagen and Jokat, 2000; Rogenhagen et al., 2004; Fig. 1). These identified three pre-glacial seismic stratigraphic units in the Weddell Sea and one in the Scotia Sea (Pw5, SH5, Sh5, SOM-C, fourth column in Table 1 and references in footnote) span the Jurassic to the end of the Oligocene. Three glacial regime units in the Weddell Sea and four in the Scotia Sea, Jane and Powell Basins were also identified. In contrast to the pre-glacial units, the glacial units were deposited over a comparatively short period of time ( $21 \mathrm{Ma})$ during the Miocene to late Pleistocene. These studies are however local scaled, stratigraphically disconnected and use different nomenclatures, making it difficult to construct regional and cross-regional sediment thickness grids.

Rooted in a $\sim 3300 \mathrm{~km}$ long transect, hereafter referred to as the Weddell Sea-Scotia Sea (WS-SS) seismic transect, this study aims to: (i) define a basin-wide seismic stratigraphic model for the Weddell Sea that is correlated to the southern Scotia Sea stratigraphy and tested against local studies and sparse boreholes; (ii) identify the preglacial (PG), transitional ( $\mathrm{T}$ ) and full glacial (FG) components in the deep-sea sediment record; (iii) quantify the sediment thicknesses, lateral age variation and tentative sedimentation rates of these components; (iv) consider the implications the findings might have for understanding the pre-glacial to glacial development of Antarctica amidst changes in climate, tectonics, and ocean circulation.

We define the pre-glacial regime as warm, predominantly ice sheet free conditions and open-ocean. The transitional regime describes a colder alpine-type climate and periods of ephemeral continental scale ice sheets that initially grounded on the outer shelf after multiple cycles of advance and retreat. The full glacial regime denotes a cold polar climate and the expansion of the ice sheets to the coast that permanently grounded on the outer shelf. Smaller advance and retreat cycles occurred, but the ice sheets remain grounded.

The WS-SS seismic transect focuses on the deep-sea sedimentary record because there the reflections are less disturbed or influenced by changes in sea level and glacial processes, making it easier to trace horizons over long distances. The thickness and geometry of the seismic sequences can give an indication of high sediment influx to the deep-sea, triggered for example by expanding ice sheets pushing sediments off the outer shelf, onto the slope and rise. The proposed age model provides a working hypothesis for further unravelling of the past ice-sheet dynamics and ocean circulation in the Weddell Sea that can be tested by future deep-sea drilling.

\section{Tectonic, palaeoceanographic and palaeoclimate setting}

The Weddell Sea basin experienced approximately 150 Ma of tectonic, palaeoceanographic and palaeoclimate history that spans the Mesozoic Gondwana break-up to the present (Table 1). Tectonic seafloor spreading in the Weddell Sea started at $\sim 147 \mathrm{Ma}$ and continued into the Eocene. Sedimentation initially started in the Weddell Sea from 138 Ma onwards (Miller et al., 1990; Rogenhagen et al., 2004), as Africa and Antarctica separated (e.g. Rogenhagen and Jokat, 2002; König and Jokat, 2006; Table 1). During the Early Eocene, Antarctica had a warm climate with high $\mathrm{pCO}_{2}$ concentrations (>1800 ppm) and sea level was about $150 \mathrm{~m}$ higher than today (e.g. Zachos et al., 2001; Miller et al., 2008). Sediment deposits formed in the Antarctic Peninsula indicate shallow water gateways (seismic lithology unit SH5 at $37 \mathrm{Ma}$ onwards in Table 1; Anderson, 2006; Smith and Anderson, 2010; Anderson et al., 2011). This was followed by Oligocene sedimentation in the Powell Basin and western Scotia Sea (e.g. seismic stratigraphic units Pw5, Sh5, Maldonado et al., 2006) during the completion of the
Weddell Sea opening (e.g. Bohoyo et al., 2002; König and Jokat, 2006; Table 1; Fig. 1).

The Eocene-Oligocene transition at $\sim 33$ Ma signifies a period of several major changes: Antarctica's climate changed from warm and relatively ice-sheet free to cold and ice-covered, as temperatures decreased by about $4{ }^{\circ} \mathrm{C}$; $\mathrm{pCO}_{2}$ declined rapidly from 1750 to $700 \mathrm{ppm}$ and orbital cycles changed (Barker, 2001; Zachos et al., 2001; DeConto and Pollard, 2003; Barker and Thomas, 2004; Coxall et al., 2005; Livermore et al., 2005; Pollard and DeConto, 2009); the Antarctic Circumpolar Current (ACC) developed (Lawver and Gahagan, 1998, 2003; Miller et al., 2008) as the Weddell Sea and Drake Passage opened and western Scotia Sea started to open (Bohoyo et al., 2002; Ghidella et al., 2002; König and Jokat, 2006; Maldonado et al., 2006); ephemeral ice sheets formed the initial East Antarctic Ice Sheet (EAIS) and West Antarctic Ice Sheet (WAIS) on higher elevations (LaBrecque et al., 1986; Barker et al., 1988; Miller et al., 1990; Oszko, 1997; Barker, 2001) as well as small ice-caps on the northern Antarctic Peninsula (Dingle and Lavelle, 1998; Smith and Anderson, 2010; Anderson et al., 2011).

In the Miocene (23.0-5.3 Ma), the EAIS, WAIS and Antarctic Peninsula Ice Sheet (APIS) growth accelerated and these ice sheets expanded to the outer shelf (dark grey bar on the right in Table 1, after e.g. Barker et al., 1988; Larter and Barker, 1989; Dingle and Lavelle, 1998; Barker, 2001; Zachos et al., 2001; Maldonado et al., 2006; Miller et al., 2008; Smith and Anderson, 2010; Davies et al., 2012). Atmospheric $\mathrm{pCO}_{2}$ levels decreased further and more rapidly from $~ 930$ to $400 \mathrm{ppm}$ during 25-23 Ma (Zachos et al., 2001; Pagani et al., 2005; Zachos and Kump, 2005; Tripati et al., 2009, 2011). Sea level decreased by 100 m (e.g. Haq and Schutter, 2008) and ocean bottom water circulation intensified between the Weddell and Scotia Seas as the ACC system developed fully (e.g. Maldonado et al., 2006).

From the Pliocene-Pleistocene, after 5.3 Ma, smaller glacial and interglacial, climate and sea-level cycles occurred in the Quaternary but the EAIS, WAIS and APIS repeatedly extended to the outer shelf in a tectonic and ocean circulation setting similar than today (Table 1).

\section{Datasets and methods}

The WS-SS seismic transect is a first approach to identify the preglacial (PG), transitional (T) and full glacial (FG) components of the deep-sea sediment record in the Weddell Sea and southern Scotia Sea (Fig. 1). All three Antarctic ice sheets, the WAIS, EAIS and APIS, drain into the Weddell Sea (red arrows, Fig. 1) making this basin a unique area to study deep-sea sediment transport and depositional processes related to ice sheet growth and demise. Magnetic seafloor spreading anomalies, seismic reflection data and ODP boreholes (Fig. 2) were used to construct an age model and estimate sedimentation rates in the following manner:

\subsection{Magnetic anomaly isochron compilation}

To constrain basement ages, obtain a spreading age range for each basin that the WS-SS seismic transect crosses and to deduct the ages of the oldest sediments that lie on the basement, we compiled a crossbasin and cross regional seafloor spreading magnetic anomaly isochron map (Fig. 2; Table 2; online Supplement 1) for the Weddell Sea and Scotia Sea from published literature (BAS, 1985; LaBrecque and Ghidella, 1997; Nankivell, 1997; Surinãch et al., 1997; Lodolo et al., 1998, 2010; Bohoyo et al., 2002, 2007; Eagles and Livermore, 2002; Ghidella et al., 2002; Kovacs et al., 2002; Eagles et al., 2005, 2006; Galindo-Zaldívar et al., 2006; König and Jokat, 2006; Maldonado et al., 2007; Eagles, 2010). This map compilation has not been published before and is available in the PANGAEA database (Lindeque et al., 2012).

Where available, magnetic anomaly picks were sourced from authors and imported into GIS ArcMap 10 (e.g. König and Jokat, 


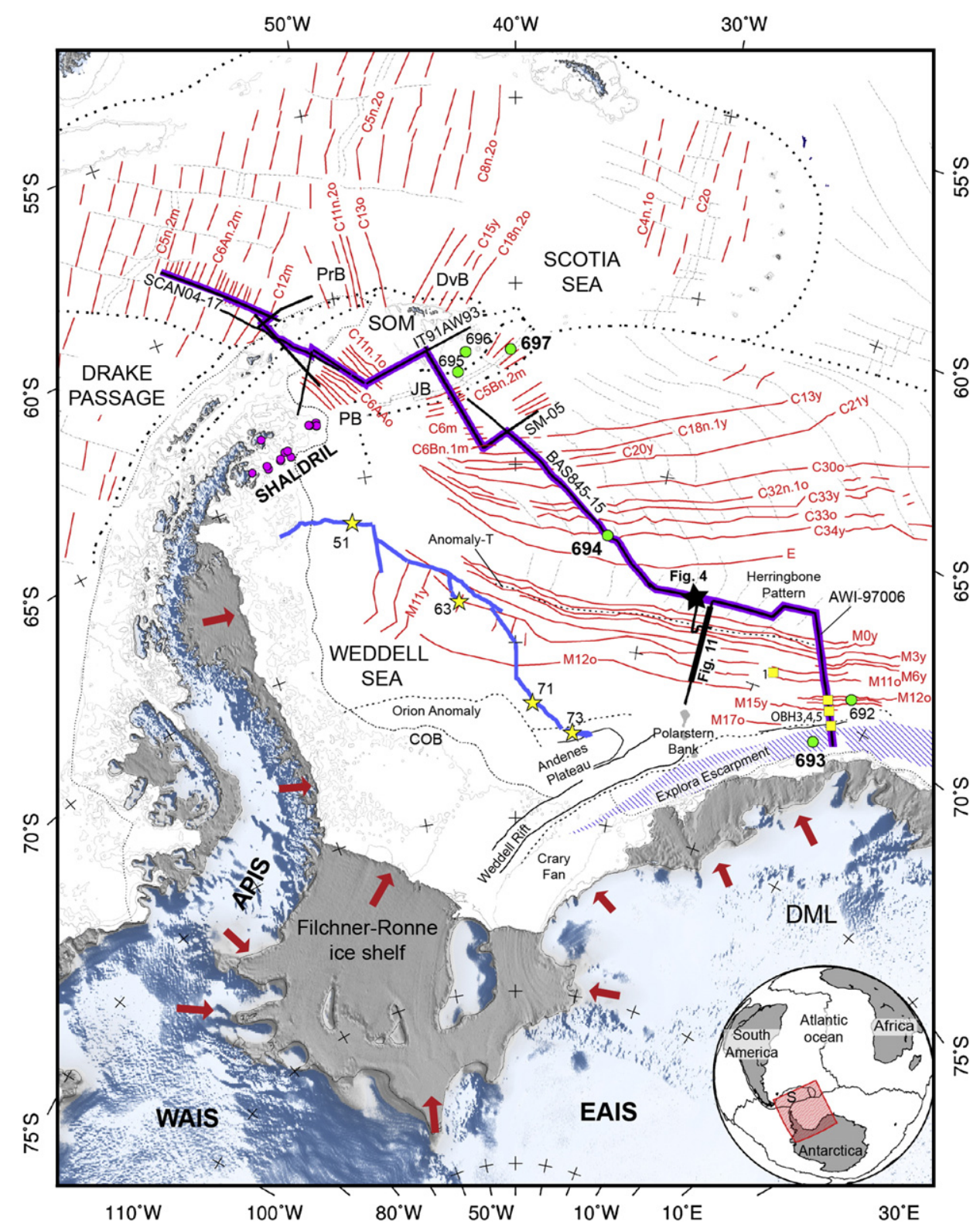

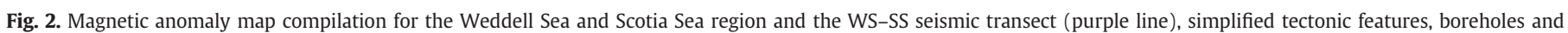

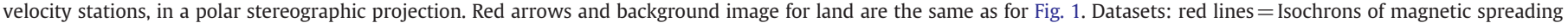

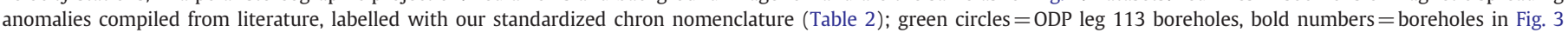

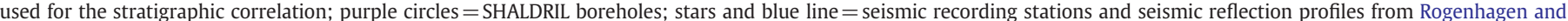

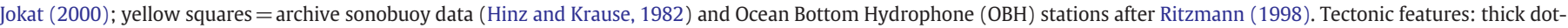

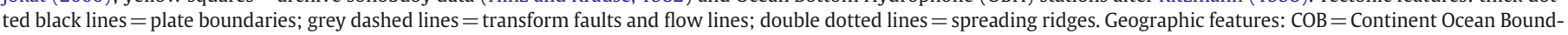
ary, $\mathrm{DML}=$ Dronning Maud Land, $\mathrm{DvB}=$ Dove Basin, $\mathrm{JB}=$ Jane Basin, $\mathrm{PB}=$ Powell Basin, $\mathrm{PrB}=$ Protector Basin, $\mathrm{SOM}=$ South Orkney Micro continent.

2006). In regions where actual magnetic data picks were unavailable, published anomaly and isochron maps (e.g. Bohoyo et al., 2002; Maldonado et al., 2007) were georeferenced and the isochrons precisely digitized. Conflicting opinions do exist between studies in the same basin e.g. in the Powell Basin between Eagles and Livermore (2002) and Surinãch et al. (1997) due to ambiguous data and allow for alternative age interpretations. In such cases, the most recent publication or best fit with the regional trend was favoured. The digitized isochrons were combined with the isochrons from the data picks and exported as an ESRI shapefile that was geospatially superimposed on the transect (thin red lines in Fig. 2; online Supplement 1). All data picks and maps were used as published.
Chron nomenclature and ages in literature (Chron-L, Age-L in Table 2) often varied between authors who applied different time scales (e.g. Cande and Kent, 1995 versus Gradstein et al., 1994). We thus standardized the nomenclature of the final selected isochrons to the Gradstein et al. (2004) timescale. Chrons were appended with $\mathrm{o}=$ old, $\mathrm{m}=$ middle, $\mathrm{y}=$ young, to indicate which part of the modelled magnetic anomaly was picked in the original literature before assigning the updated chron nomenclature (respectively named Chron and Age in Table 2). The ages of the C-chron series slightly changed between the Gradstein et al. (2004) scale (used in this study) and the Cande and Kent (1995) scale. More significant age changes occurred in the M-series (Table 2) for example: chron MOy 
Table 2

Isochrons of magnetic spreading anomalies crossing the Weddell Sea-Scotia Sea (WS-SS) seismic transect, see Fig. 2.

\begin{tabular}{|c|c|c|c|c|c|c|c|c|c|}
\hline \multicolumn{2}{|c|}{ This study } & \multicolumn{2}{|c|}{ Literature } & \multirow{2}{*}{$\begin{array}{l}\text { Profile } \\
\text { number }\end{array}$} & \multicolumn{2}{|c|}{ This study } & \multicolumn{2}{|c|}{ Literature } & \multirow{2}{*}{$\begin{array}{l}\text { Profile } \\
\text { number }\end{array}$} \\
\hline Chron & Age & Chron-L & Age-L & & Chron & Age & Chron-L & $\overline{\text { Age-L }}$ & \\
\hline \multicolumn{5}{|c|}{ Scotia Sea } & \multicolumn{5}{|c|}{ Northeastern Weddell Sea } \\
\hline C5n.2m & 10.5 & $\mathrm{C} 5 \mathrm{n}$ & 9.8 & SCAN04-17 & $\mathrm{c} 6 \mathrm{~m}$ & 19.2 & C6n & 19.5 & $\mathrm{SM} 04^{2}$ \\
\hline C5An.2m & 12.3 & C5An & 12.3 & SCAN04-17 ${ }^{1}$ & C6An.1m & 20.1 & C6An.1n & 20.0 & $\mathrm{SM} 04^{2}$ \\
\hline C5Bn.2m & 15.1 & C5Bn.2n & 15.1 & SCAN04-17 ${ }^{1}$ & C6An.2m & 20.5 & C6An.2n & 20.4 & $\mathrm{SM}^{2} 4^{2}$ \\
\hline $\mathrm{C} 5 \mathrm{Cn} .2 \mathrm{~m}$ & 16.4 & $\mathrm{C} 5 \mathrm{Cn}$ & 16.4 & SCAN04-17 & C6Bn.1m & 22.6 & C6Bn & 22.0 & $\mathrm{SM} 04^{2}$ \\
\hline C5Dm & 17.4 & C5Dn & 17.3 & SCAN04-17 1 & C6Cn.3m & 23.3 & $\mathrm{C} 6 \mathrm{Cn}$ & 24.0 & $\mathrm{SM}^{2} 4^{2}$ \\
\hline C5Em & 18.3 & C5En & 18.2 & SCAN04-17 1 & C7n.2m & 24.4 & $\mathrm{C7n}$ & 25.0 & $\mathrm{SM} 04^{2}$ \\
\hline C6m & 19.2 & C6n & 19.2 & SCAN04-17 ${ }^{1}$ & \multicolumn{5}{|c|}{ Central Weddell Sea } \\
\hline C6An.2m & 20.5 & C6An.2n & 20.0 & SCAN04-17 $17^{1}$ & C13y & 33.3 & $\mathrm{C} 13$ & 33.1 & BAS $845-15^{5}$ \\
\hline C6Bn.2m & 22.1 & C6Bn & 21.9 & SCAN04-17 & C18n.1y & 38.0 & C18 & 38.4 & BAS $845-15^{5}$ \\
\hline C6Cn.2m & 23.0 & $\mathrm{C} 6 \mathrm{Cn}$ & 23.0 & SCAN04-17 & $\mathrm{C} 20 \mathrm{y}$ & 41.6 & $\mathrm{C} 20$ & 42.5 & BAS $845-15^{5}$ \\
\hline C7n.2m & 24.4 & C7n & 24.1 & SCAN04-17 ${ }^{1}$ & C21y & 45.3 & $\mathrm{C} 21$ & $46.2,47.9$ & BAS $845-15^{5,6}$ \\
\hline C7Am & 25.4 & C7An & 25.0 & SCAN04-17 $17^{1}$ & C30o & 67.7 & $\mathrm{C} 30$ & 67.6 & BAS $845-15^{6}$ \\
\hline C8n.2m & 25.8 & C8n & 25.4 & SCAN04-17 $1{ }^{1}$ & C32n.1o & 71.2 & C32n.1 & 71.3 & BAS $845-15^{7}$ \\
\hline $\mathrm{c} 9 \mathrm{~m}$ & 27.3 & C9n, C9 & $27.2,27.7$ & SCAN04-17 $17^{1,4}$ & C33y & 73.6 & C33 & 73.6 & BAS $845-15^{7}$ \\
\hline C10n.1y & 28.1 & $\mathrm{C} 10$ & 28.0 & $\mathrm{M}_{0} 5^{4}$ & C33o & 79.5 & $\mathrm{C} 33 \mathrm{r}$ & 79.0 & BAS $845-15^{7}$ \\
\hline C10n.2y & 28.5 & C10n & 28.5 & SCAN04-17 $1{ }^{1}$ & C34y & 84.0 & C34 & 83.0 & BAS $845-15^{8}$ \\
\hline C11n.1m & 29.6 & C11n & 29.5 & SCAN04-17 ${ }^{1}$ & E & 93.0 & E & 93.0 & BAS $845-15^{5}$ \\
\hline \multirow[t]{2}{*}{$\mathrm{C} 12 \mathrm{~m}$} & 30.9 & $\mathrm{C} 12 \mathrm{n}$ & 30.9 & SCAN04-17 & \multicolumn{5}{|c|}{ Southwestern Weddell Sea } \\
\hline & & \multicolumn{2}{|c|}{ Powell Basin } & & M0y & 124.6 & M0 & 118,121 & $97006^{9}, 10^{9}, 30^{9}$ \\
\hline C6AAo & 21.1 & C6AA & 21.8 & IT89AW41 ${ }^{3}$ & M1o & 127.2 & M1n & 122.0 & $97006^{9}, 10^{9}, 30^{9}$ \\
\hline C6Cn.3o & 23.4 & $\mathrm{C} 6 \mathrm{C}$ & 24.1 & IT91AW90 3 & M3y & 127.6 & M3 & 123.0 & $97006^{9}, 10^{9}, 28^{9}, 30^{9}$ \\
\hline C7n.2o & 24.5 & $\mathrm{C} 7$ & 24.7 & IT91AW92 $^{3}$ & M5y & 129.8 & M4 & 125.4 & $97006^{9}, 10^{9}, 29^{9}$ \\
\hline C8n.2o & 26.1 & $\mathrm{C} 8$ & 26.5 & IT91AW93 $^{3}$ & M6y & 131.2 & M5 & 127.0 & $97006^{9}$ \\
\hline $\mathrm{C} 9 \mathrm{O}$ & 27.8 & C9 & 27.9 & IT91AW93 $^{3}$ & M10y & 133.5 & M10 & 130.2 & $97006^{5}, 10^{5}$ \\
\hline C10n.1o & 28.4 & $\mathrm{C} 10$ & 28.5 & IT91AW93 $^{3}$ & M11y & 135.7 & $\mathrm{M} 10 \mathrm{Nr}$ & 131.5 & $97006^{8}, 10^{8}$ \\
\hline C11n.1o & 29.7 & C11 & 29.7 & IT91AW93 $^{3}$ & M12o & 137.8 & M11, M12 & 133,134 & $97006^{8,9}, 10^{8,9}$ \\
\hline \multicolumn{5}{|c|}{ Jane Basin } & M12r.1y & 138.6 & $\mathrm{M} 12.1 \mathrm{~N}$ & 135.6 & $97006^{9}$ \\
\hline C5ADm & 14.4 & C5ADn & 14.4 & $\mathrm{SM} 04^{2}$ & M13o & 139.3 & M13 & 136.6 & $97006^{9}$ \\
\hline C5Bn.2m & 15.1 & C5Bn.2n & 15.1 & $\mathrm{SM} 04^{2}$ & M15y & 140.4 & M15n & 138.3 & $97006^{9}$ \\
\hline C5Cn.3m & 16.6 & $\mathrm{C5Cn}$ & 16.6 & $\mathrm{SM} 04^{2}$ & M17o & 142.8 & M17 & 142.3 & $96110^{9}$ \\
\hline
\end{tabular}

$\mathrm{C} 5 \mathrm{Dm}$ 17.4

C5Dn $\quad 17.6$

$\mathrm{SM} 04^{2}$

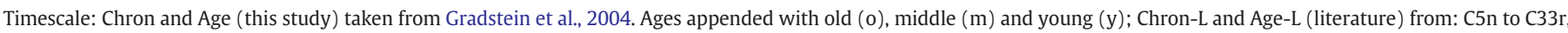
Cande and Kent, 1995; C34 to E, Barker, 2001, 1994; M0 to M17, Kent and Gradstein 1986; Gradstein et al., 1994.

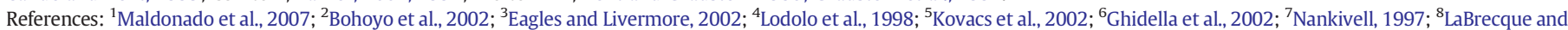
Ghidella, 1997; ${ }^{9}$ König and Jokat, 2006. All ages are in Ma.

is now 124.6 Ma according to the Gradstein et al. (2004) scale, but was previously $118-121 \mathrm{Ma}$ in the Cande and Kent (1995) scale used in Rogenhagen et al. (2004).

\subsection{Borehole stratigraphy}

We projected Ocean Drilling Program (ODP) leg 113 borehole sites 693, 694 and 697 (Barker et al., 1988) into the WS-SS seismic transect (Figs. 2 and 3). The projection path was chosen parallel to the contour or bathymetric feature (e.g. shelf edge, basin or ridge) in order to ensure the most accurate correlation. Site 693 lies $\sim 65 \mathrm{~km}$ to the west of the transect, site 694 is line coincident and site 967 lies $\sim 200 \mathrm{~km}$ to the east of the transect (Fig. 2). To compensate for these large offsets, the borehole horizons were matched to horizons in coincident seismic lines and traced along a series of crossing seismic tie lines until the horizon could be matched to equivalent reflectors in the WS-SS seismic transect data in order to obtain a stratigraphic age constrain for the upper $300 \mathrm{~m}$ (Fig. 3). The following seismic tie lines were 


\section{A) ODP leg 113 site 697}
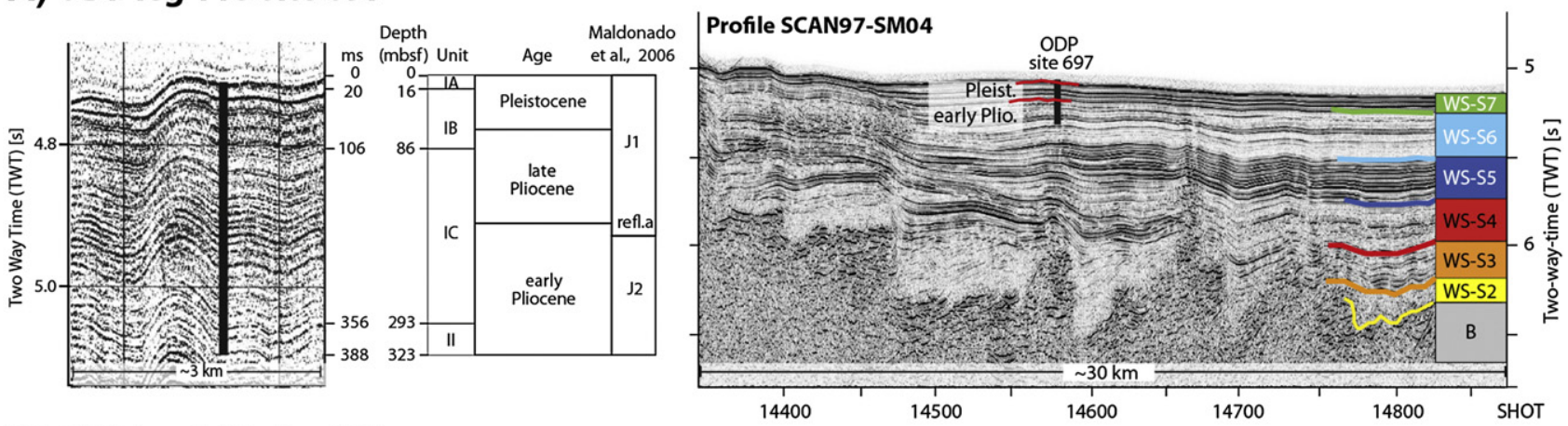

\section{B) ODP leg 113 site 694}
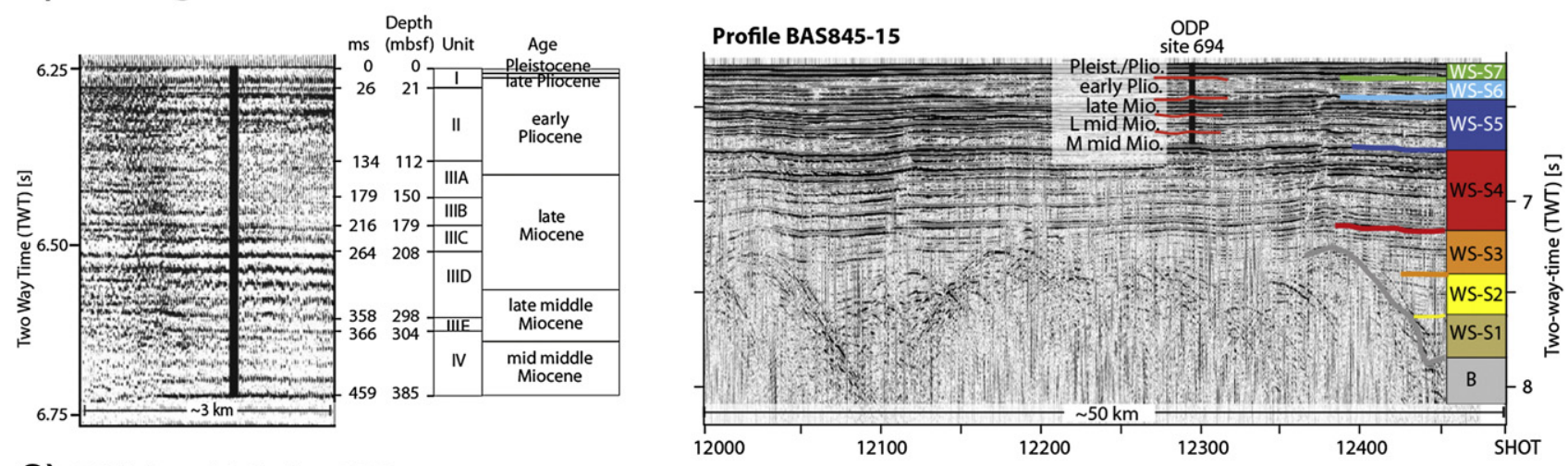

\section{C) ODP leg 113 site 693}

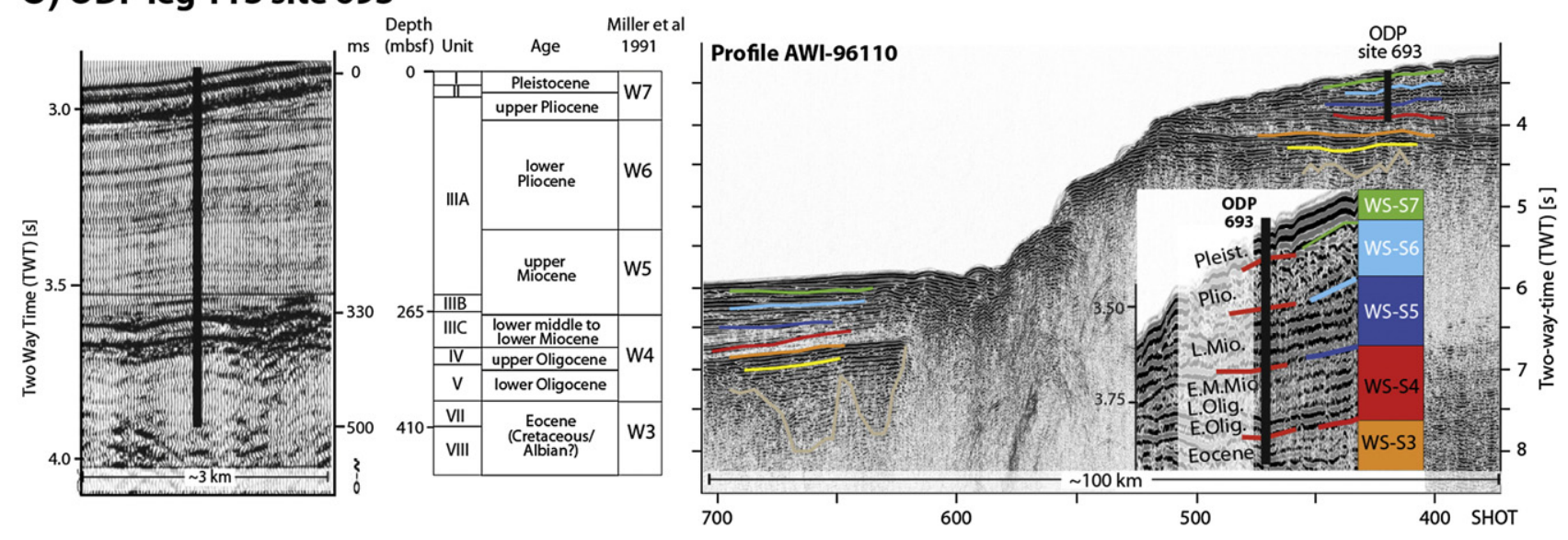

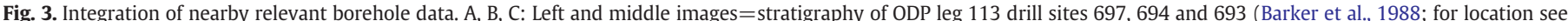

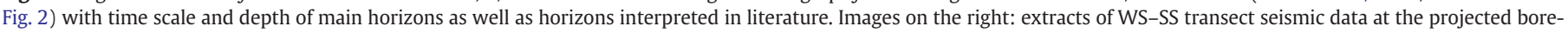

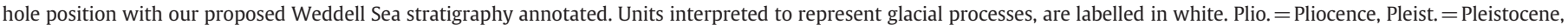
Mio. $=$ Miocene, Olig. $=$ Oligocene.

used: for site 697, lines IT91AW93, SM04 and SM05; none for site 694 as it lies directly on the transect; and for site 693, lines BGR78018, BGR78019, BGR86006 and BGR87097. Most of the seismic lines used are available in the Seismic Data Library System (SDLS; Wardell et al., 2007). Recent SHALDRIL boreholes on the Antarctic Peninsula (Smith and Anderson, 2011) were also incorporated and connected to the transect via tie lines IT91AW90, M08, BAS84-154 to cruise NBP0602A

\subsection{Seismic characterization}

A transect of continuous seismic data through the central Weddell Sea basin and parallel to the margin was required to ensure the most representative deep-sea data for interpretation. Multichannel seismic
(MCS) reflection profiles collected on several expeditions of various organisations in the SDLS databank (Wardell et al., 2007), collectively form three transects across the central Weddell Sea (A, B, C in Fig. 1). Transects $A$ and $C$ provide seismic reflection data from the southeastern to northwestern Weddell Sea, but do not connect to or cross any seismic profiles at the Antarctic Peninsula, and hence were considered unsuitable for the objectives of this work (yellow ovals in Fig. 1 mark data gaps). The middle transect (B) was chosen for tracing the horizons because there are no data gaps between profiles and the transect is most representative of the deep-sea sedimentary archive, because it runs more or less through the middle of the Weddell Sea basin (red dashed outline in Fig. 1). Typical seismic characteristics defined in other studies through drilling and seismic reflection data (e.g. Bellingshausen Sea: Scheuer et al., 2006; Cosmonaut Sea: Leitchenkov et al., 2007, 2008; 
WS-S7

Channel and basin fill-in, smoothing the surface. High amplitude, finely laminated continuous unit.

WS-S6

Finely laminated, high amplitude continuous reflections. Parts are chaotic reflections with lower reflectivity due to debris flows.

WS-S5

Highest amplitude sequence, strongly laminated, unconformities and stacked. Chaotic structure between high amplitude reflections.

WS-S4

Medium reflectivity, discontinuous and horizontal reflections. A higher amplitude reflector often divides the sequence in two parts.

WS-S3

Lower amplitude sequence with strong discontinuous reflections in parts.

WS-S2

Horizontal, evenly spaced, high amplitude reflections against a low amplitude to transparrent background.

\section{WS-S1}

Transparent to very high amplitude reflections. Unit discontinuous.

WS-SO

Acoustic basement, probably crystalline or consolidated / meta-sediments below.

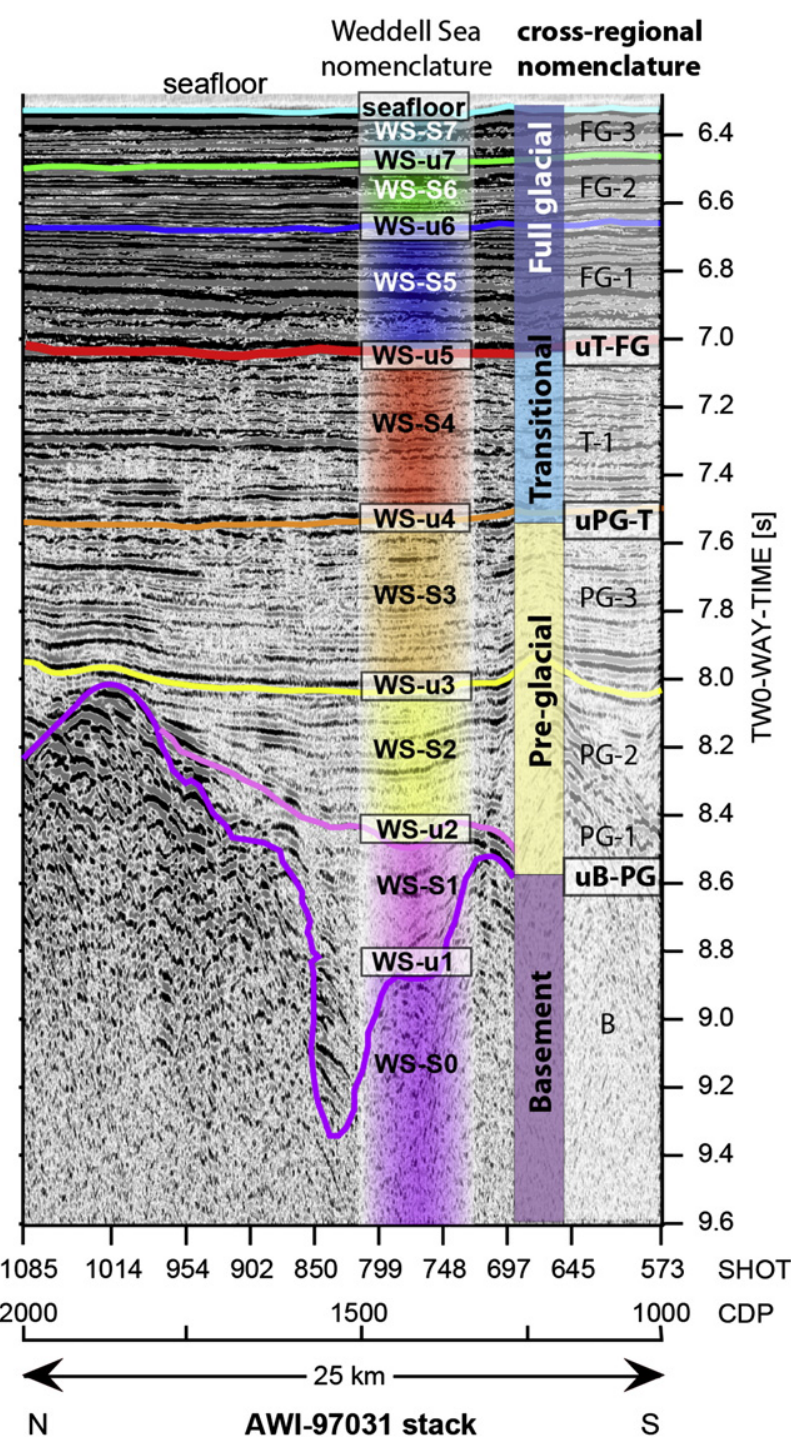

AWI-97031 stack

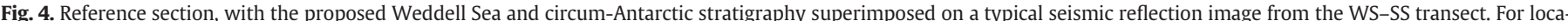

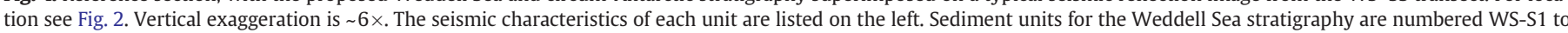

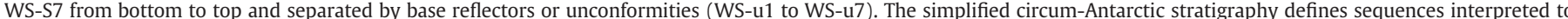

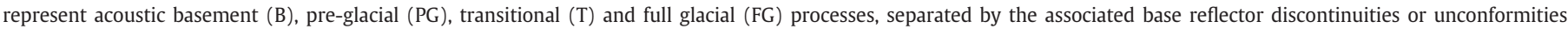
(uB-PG, uPG-T and uT-FG).

Wilkes Land: DeSantis et al., 2003; Escutia et al., 2011) were used as a guide to identify the pre-glacial to glacial units; briefly summarised as follows:

The pre-glacial seismic facies are usually the first layers above basement. They show diagnostic low amplitude to transparent reflectivity and stronger discontinuous reflectors therein, appearing light grey to almost white in the seismic image. The transitional regime depicts a change in the deposition processes since reflectors are now closer spaced, horizontal and mostly continuous with medium amplitude. These characteristics often result in a medium grey appearance in seismic sections without gain adjustment on display. The continuous, high amplitude reflectors represent the full glacial sequence. Deposits from sporadic down-slope sediment transport generally result in complex internal structures and form turbidite channel-levee systems, or chaotic bodies in the case of debris-flow processes. Persistent bottom-currents that flow along-slope or oblique to the contours develop various types of contourites of which the sheeted and mounded drifts are the most prominent in this case. This sequence typically appears dark grey to black in seismic images and is the first layers below the seafloor.
Using these characteristic seismic facies changes, borehole correlation (Figs. 2 and 3) and other seismic stratigraphy models in the southeastern (Miller et al., 1990) and the northwestern Weddell Sea (Maldonado et al., 2006) as guidelines, we compiled a type section for the WS-SS seismic transect data (Fig. 4). A part of profile AWI-97030 was chosen from several other good example sections because: (1) it lies in the deeper part of the basin, (2) is close enough for correlations to the slope, (3) is a good representation of the changes in seismic facies, and (4) all the seismic units are present. See location of the type section in Fig. 2. We assigned a new bottom-to-top stratigraphy nomenclature for the Weddell Sea and proposed circum-Antarctic units (Fig. 4). The resulting model seismic stratigraphy was used as a template to interpret, or re-interpret the rest of the WS-SS seismic transect data.

Twenty-three MCS profiles were used to construct the $\sim 3300 \mathrm{~km}$ long WS-SS seismic transect (Fig. 1; Table 3). All navigation data and some of the seismic reflection data (IT91 and BAS845 cruises) are public domain legacy data in the SDLS. Seismic data of profiles AWI-970x were in-house at AWI, and SEGY data of the Spanish lines (cruises SCAN-2004, HESANT-92/93, and SCAN-97) were provided for this 
Table 3

Seismic reflection profiles used to construct the Weddell Sea-Scotia Sea (WS-SS) seismic transect.

\begin{tabular}{|c|c|c|c|c|c|c|c|c|}
\hline Profile & Cruise & $\begin{array}{l}\text { CDP } \\
\text { spacing } \\
{[\mathrm{m}]}\end{array}$ & $\begin{array}{l}\text { Source } \\
\text { (\# airguns } \times \\
\text { volume [L]) }\end{array}$ & $\begin{array}{l}\text { Streamer } \\
\text { (channels/ } \\
\text { length }[\mathrm{m}] \text { ) }\end{array}$ & $\begin{array}{l}\text { Profile } \\
\text { length } \\
{[\mathrm{km}]}\end{array}$ & $\begin{array}{l}\text { Processing } \\
\text { stage of } \\
\text { seismic data } \\
\text { used }\end{array}$ & Area & $\begin{array}{l}\text { Institute, } \\
\text { References }\end{array}$ \\
\hline SCAN04-17 & SCAN-2004 & 25 & $7 \times 16.40$ & $96 / 2400$ & 390 & migrated & Scotia sea & $\mathrm{a}, 1$ \\
\hline M31 & HESANT-92/93 & 6.25 & $6 \times 15.26$ & $96 / 1200$ & 197 & migrated & Scotia sea & a, 2,3 \\
\hline M05 & HESANT-92/93 & 6.25 & $6 \times 15.26$ & $96 / 1200$ & 304 & migrated & Powell basin & a, 2,3 \\
\hline IT89AW41 & IT90AP & 12.5 & $18 \times 2.51$ & $120 / 2975$ & 206 & stack & Powell basin & b, 4 \\
\hline IT91AW90 & IT91AP & 25 & $18 \times 2.68$ & $120 / 2975$ & 208 & stack & Powell basin & b, 4 \\
\hline IT91AW91 & IT91AP & 25 & $18 \times 2.68$ & $120 / 2975$ & 147 & stack & Powell basin & b, 4 \\
\hline IT91AW92 & IT91AP & 25 & $18 \times 2.68$ & $120 / 2975$ & 56 & stack & Jane basin & b, 4 \\
\hline IT91AW93 & IT91AP & 25 & $18 \times 2.68$ & $120 / 2975$ & 374 & stack & Jane basin & b, 5 \\
\hline SM04 & SCAN-97 & 12.5 & $5 \times 22.4$ & $96 / 2400$ & 362 & migrated & Jane basin & a, $2,6,7,8$ \\
\hline SM05 & SCAN-97 & 12.5 & $5 \times 22.4$ & $96 / 2400$ & 231 & migrated & Jane basin & a, $2,6,7$ \\
\hline BAS845-15 & BAS-84 & 25 & $4 \times 8.5$ & $48 / 2400$ & 832 & stack & central weddell sea & c, 9 \\
\hline AWI-97032 & ANT-XIV/3 & 25 & $6 \times 18$ & $96 / 2400$ & 27 & stack & eastern weddell sea & $\mathrm{d}, 10,11,12$ \\
\hline AWI-97031 & ANT-XIV/3 & 25 & $6 \times 18$ & $96 / 2400$ & 138 & stack & eastern weddell sea & $\mathrm{d}, 10,11,12$ \\
\hline AWI-97030 & ANT-XIV/3 & 25 & $16 \times 3$ & $96 / 2400$ & 109 & stack & eastern weddell sea & $\mathrm{d}, 10,11,12$ \\
\hline AWI-97029 & ANT-XIV/3 & 25 & $7 \times 21$ & $96 / 2400$ & 14 & stack & eastern weddell sea & $\mathrm{d}, 10,11,12$ \\
\hline AWI-97028 & ANT-XIV/3 & 25 & $7 \times 21$ & $96 / 2400$ & 16 & stack & eastern weddell sea & $\mathrm{d}, 10,11,12$ \\
\hline AWI-97027 & ANT-XIV/3 & 25 & $7 \times 21$ & $96 / 2400$ & 43 & stack & eastern weddell sea & $\mathrm{d}, 10,11,12$ \\
\hline AWI-97010 & ANT-XIV/3 & 25 & $6 \times 18$ & $96 / 2400$ & 335 & stack & eastern weddell sea & $\mathrm{d}, 10,11,12$ \\
\hline AWI-97009 & ANT-XIV/3 & 25 & $6 \times 18$ & $96 / 2400$ & 194 & stack & eastern weddell sea & $\mathrm{d}, 10,11,12$ \\
\hline AWI-97008 & ANT-XIV/3 & 25 & $6 \times 18$ & $96 / 2400$ & 49 & stack & eastern weddell sea & $\mathrm{d}, 10,11,12$ \\
\hline AWI-97007 & ANT-XIV/3 & 25 & $6 \times 18$ & $96 / 2400$ & 99 & stack & eastern weddell sea & $\mathrm{d}, 10,11,12$ \\
\hline AWI-97006 & ANT-XIV/3 & 25 & $16 \times 3$ & $96 / 2400$ & 312 & stack & eastern weddell sea & d, $10,11,12$ \\
\hline \multirow[t]{2}{*}{ AWI-96110 } & ANT-XIII/3 & 50 & $6 \& 60$ & $96 / 2400$ & 224 & stack & eastern weddell sea & $\mathrm{d}, 13$ \\
\hline & & & & Total km & 4867 & & & \\
\hline
\end{tabular}

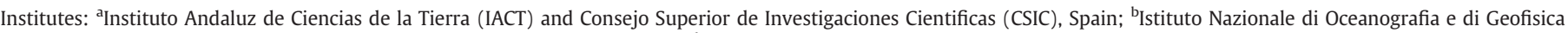

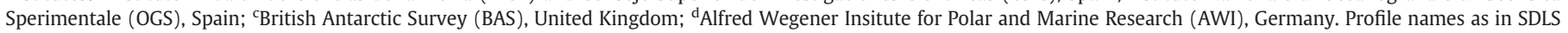
database (Wardell et al., 2007).

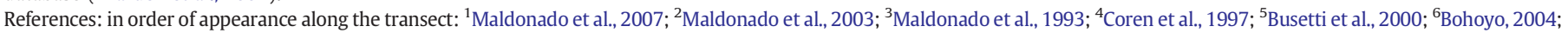

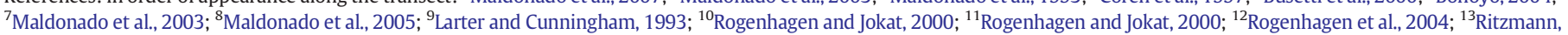
1998.

study from the cooperating Institute (Table 3). The MCS data are unmigrated or migrated stacked time sections and used as received without additional processing or conversion into a depth section. The 23 profiles were joined at the exact line intersections from northwest to southeast, resulting in a basin-wide seamless seismic reflection profile (Figs. 5A and 6A, online Supplements 2 and 3). No time and phase shifts were necessary to match the profiles. The magnetic spreading anomaly isochrons (Fig. 2) and nearby ODP leg 113 boreholes (Fig. 3) were projected into the transect seismic image (red dashed lines and black arrows in Figs. 5A and 6A) to constrain the interpretation and basement age. The interpretation of the upper units was tested against borehole stratigraphic correlations (Fig. 3) and type section (Fig. 4). Thereafter we traced the strongest, undisturbed and most prominent seismic reflections and discontinuities, which define the basal boundaries of the sequences in the reference section, for the full transect length and present a basin-wide stratigraphy (Figs. 5B and 6B, online Supplements 2 and 3).

\subsection{Sediment thickness estimates}

Sediment thickness-depth sections were constructed from 13 points along the WS-SS seismic profile (Figs. 5-7). These particular points were chosen so as to represent the major changes in the seismic facies and basin geometry, and are therefore not equidistant. Interval velocities from wide-angle seismic refraction data provide the nearest velocity information (Rogenhagen and Jokat, 2000, yellow stars Fig. 1) and were supplemented by velocity data deducted from sonobuoy (station 1, Hinz and Krause, 1982) and ocean bottom hydrophones (OBH3, 4, 5, Ritzmann, 1998) experiment observations. The velocity model from station 1 divided the sediments into two units and the velocity model at $\mathrm{OBH} 3,4$ and 5, divided deep-sea sediments into three or four units. This was problematic because an average velocity for each seismic unit was needed. To resolve it, the data from these four stations were combined into one velocity function and applied to points 11, 12 and 13 (Fig. 7C). The sediment layer division of Rogenhagen et al. (2004) often varied from our interpreted WS-SS stratigraphy and an interpolated velocity was calculated for each sedimentary unit in proportion to the thickness. The full velocity model is available as online Supplement 4.

Uncertainties in the sediment thickness of up to $70 \mathrm{~m}$ occur since the two-way-time picks can differ by one or two reflections ( $\sim 30 \mathrm{~ms})$ depending on visual interpretation. The uncertainty in interval velocities from refraction data is qualitatively estimated at $\sim 0.1 \mathrm{~km} / \mathrm{s}$. Interval velocity in the same seismic unit change over distance due to increased 


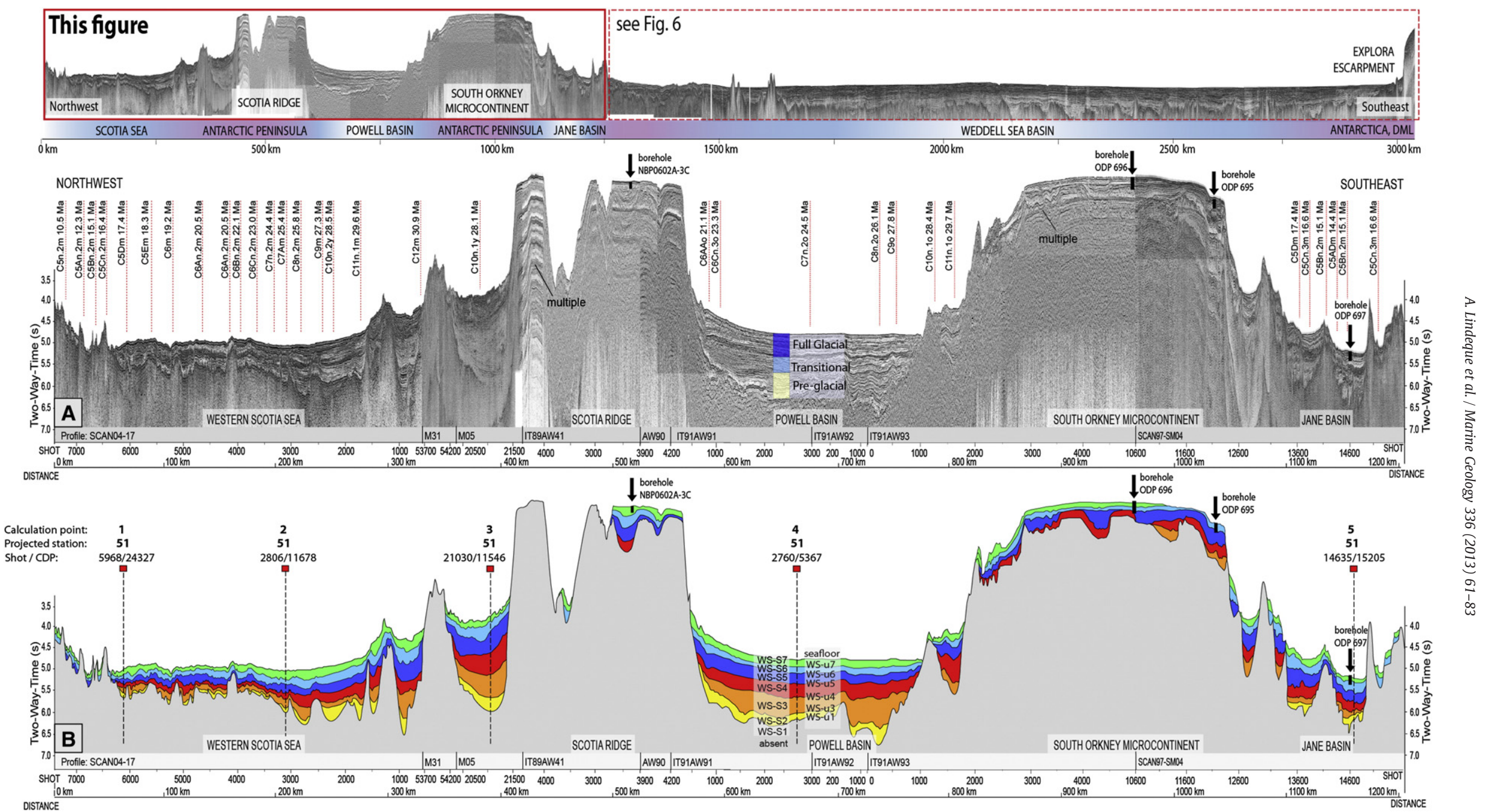

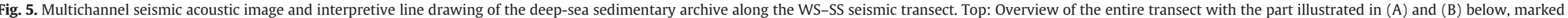

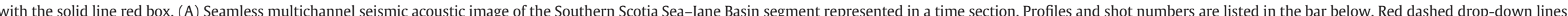

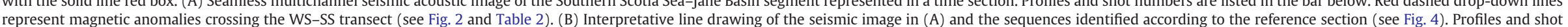
numbers are listed in the bar below. Red squares and dashed drop-down lines represent points selected for sediment thickness and sedimentation rate calculations. 


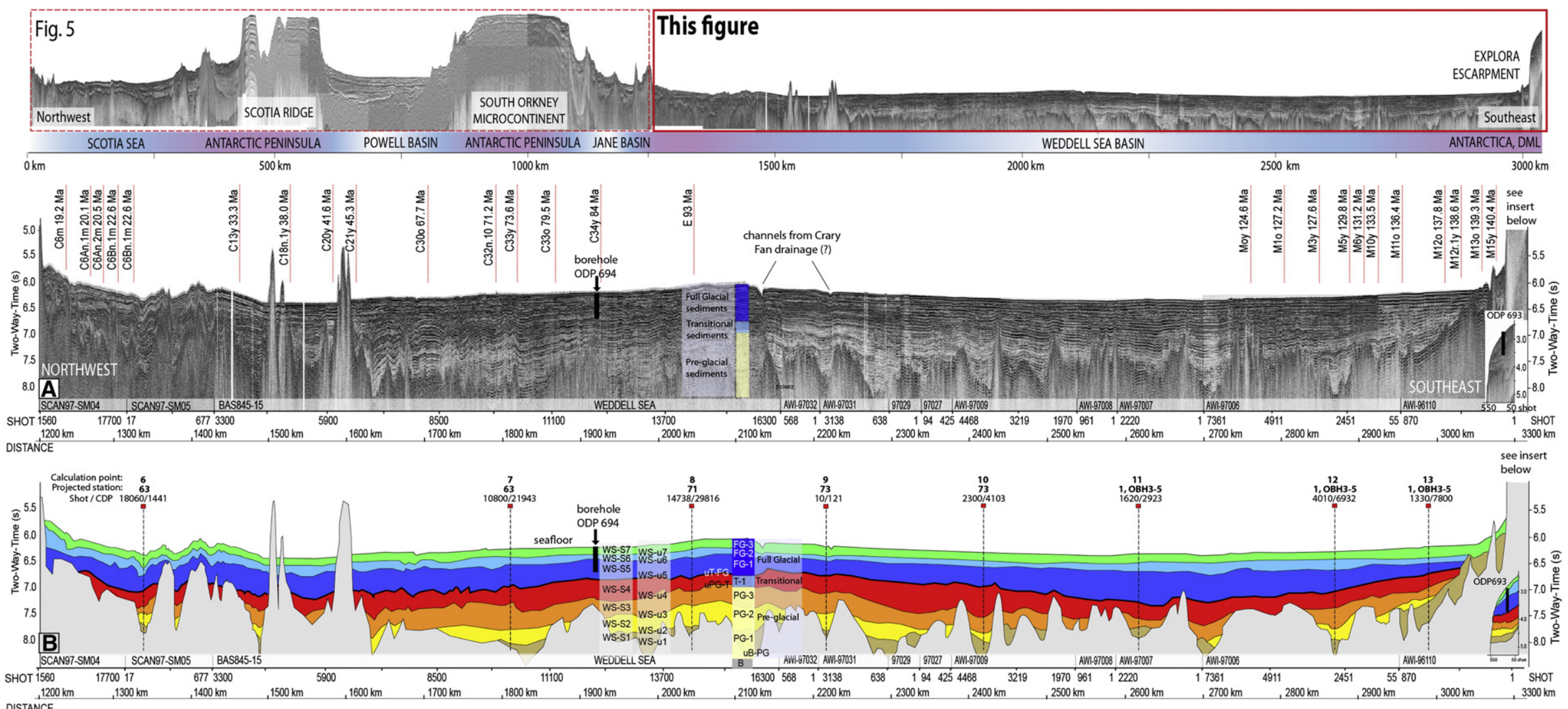
DISTANCE

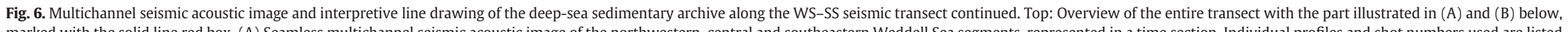

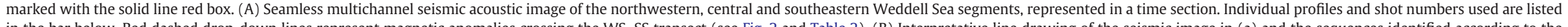

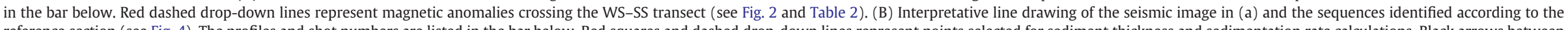

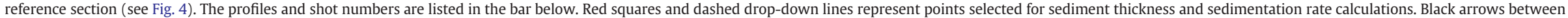
points 8 and 9 indicate channel-levee geomorphology, possibly related to the Crary Fan drainage channel-system (Michels et al., 2001, 2002) or bottom current activity. 

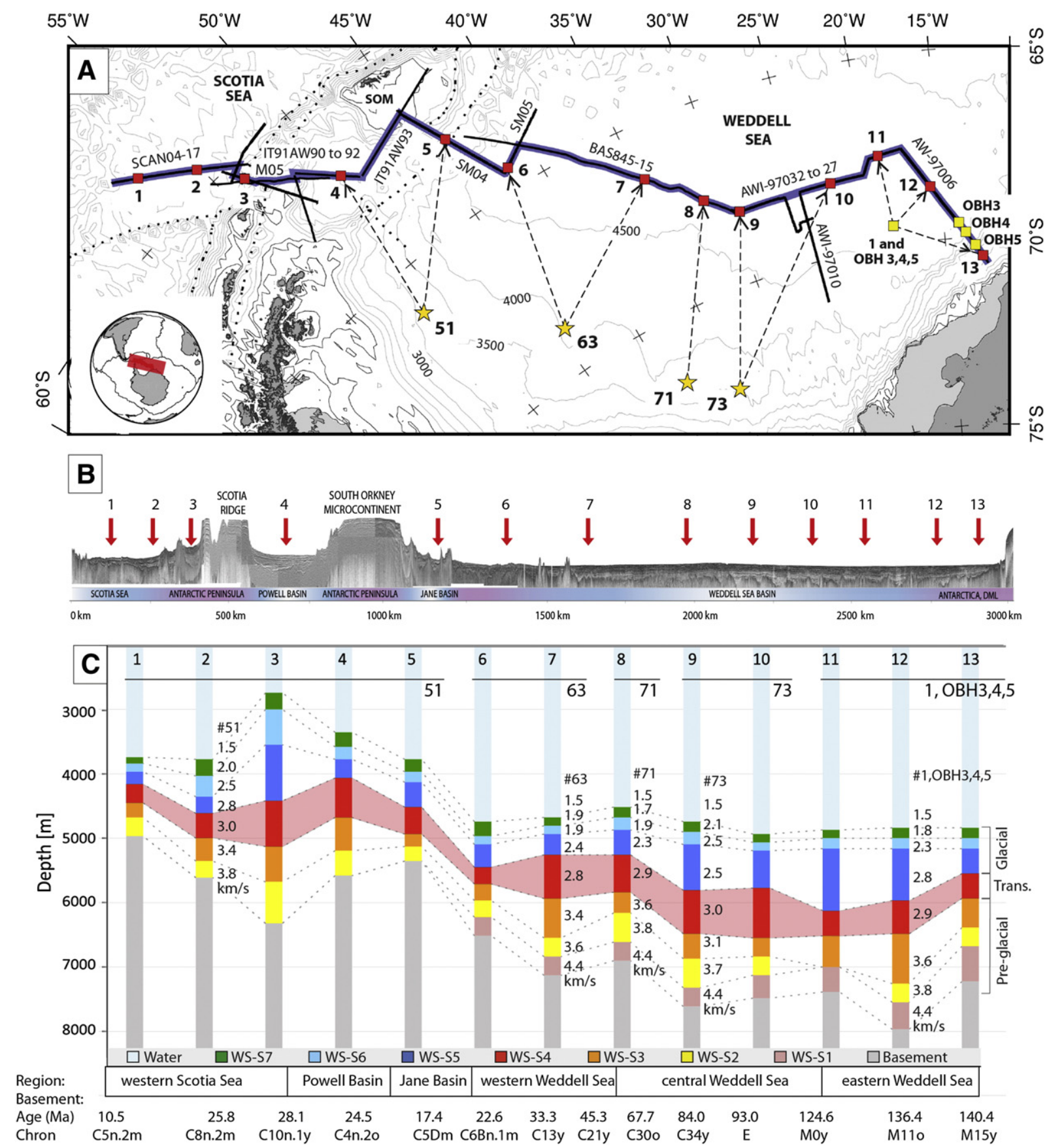

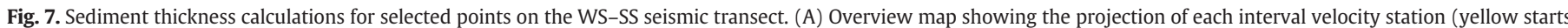

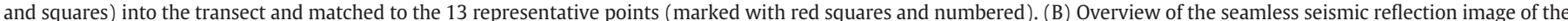

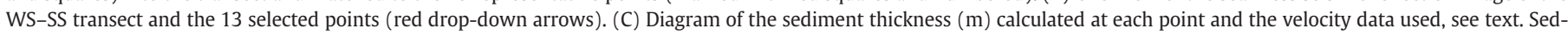

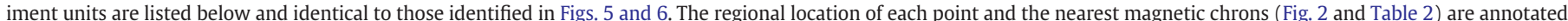
below.

compaction from more overburden and therefore using velocity data $\sim 500 \mathrm{~km}$ from the transect introduce further uncertainties. Even so, the interval velocity model used was compiled from all available data nearest to the transect and in the Weddell Sea basin.

We minimize these uncertainties by assigning similar velocities to units with the same seismic facies characteristics. Velocity information from station 51 was used to calculate sediment thickness at points 1 to 5 ; station 63 for points 6 and 7 ; station 71 for point 8 ; and station 73 for points 9 and 10 (Fig. 7B and C). The resulting depth-sediment thickness diagram is shown in Fig. 7C and the sediment thickness for the pre-glacial to glacial units at each point are summarised in Table 4 and online Supplement 5.

\subsection{Age model and sedimentation rate estimates}

Our study is of basin-wide scale and since boreholes are few and far between, we constructed a hypothetical working age model as follows: a simplified Gradstein et al. (2004) geological time scale was re-drawn to a measurable vertical scale (Fig. 8, far left). The spreading age-range for each basin on the WS-SS seismic transect was taken from the magnetic anomaly compilation (Fig. 2 and Table 2) and drawn against the time scale (Fig. 8, black bars labelled sw SS, JB, PB and WS). The nearest isochron was taken at each of the 13 points used for the sediment thickness calculation, or linearly interpolated between the two closest anomalies, and matched to the time scale. 
Table 4

Sediment thickness and sedimentation rate estimates at selected points on the WS-SS seismic transect, derived from the data in Figs. 1,2 and 6 to 10.

\begin{tabular}{|c|c|c|c|c|c|c|c|c|}
\hline \multirow[b]{2}{*}{ Point } & \multirow[b]{2}{*}{ Region } & \multicolumn{4}{|c|}{ Sedimentation thickness (m) } & \multicolumn{3}{|c|}{ Sedimentation rate $(\mathrm{cm} / \mathrm{ky})$} \\
\hline & & Total & Pre-glacial & Transitional & Glacial & Pre-glacial & Transitional & Glacial \\
\hline 1 & & 1221 & 498 & 295 & 428 & 8.7 & 12.8 & 4.4 \\
\hline 2 & Scotia sea & 1827 & 626 & 378 & 824 & 7.4 & 6.9 & 7.0 \\
\hline 3 & & 3582 & 1172 & 726 & 1684 & 10.7 & 11.2 & 16.0 \\
\hline 4 & Powell basin & 2227 & 918 & 625 & 683 & 10.4 & 10.8 & 7.0 \\
\hline 5 & Jane basin & 1580 & 441 & 389 & 749 & 10.5 & 11.5 & 9.9 \\
\hline 6 & northwestern & 1756 & 803 & 269 & 685 & 10.7 & 5.7 & 6.3 \\
\hline 7 & Weddell sea & 2455 & 1205 & 666 & 583 & 2.4 & 9.5 & 4.2 \\
\hline 8 & & 2386 & 1058 & 571 & 757 & 1.5 & 9.8 & 4.4 \\
\hline 9 & central & 2872 & 1130 & 656 & 1085 & 1.4 & 8.2 & 7.8 \\
\hline 10 & Weddell sea & 2531 & 923 & 780 & 827 & 1.1 & 6.1 & 6.1 \\
\hline 11 & & 2524 & 894 & 383 & 1248 & 1.5 & 1.2 & 4.7 \\
\hline 12 & $\begin{array}{l}\text { southeastern } \\
\text { Weddell sea }\end{array}$ & 3136 & 1481 & 522 & 1132 & 1.4 & 6.4 & 6.4 \\
\hline 13 & & 2405 & 1298 & 392 & 715 & 1.2 & 4.4 & 4.1 \\
\hline
\end{tabular}

$\mathrm{m}=$ meters, $\mathrm{m} / \mathrm{my}=$ meters per one million years, $\mathrm{ms}=$ milliseconds, red $=$ minimum values, blue $=$ maximum values .

Pre-glacial: Seismic stratigraphic units WS-S1, WS-S2 and WS-S3 shown in Fig. 6 and 7.

Transitional: unit WS-S4 and Glacial: units WS-S5, WS-S6 and WS-S7.

Uncertainty in sediment thickness $\sim 30 \mathrm{~ms}$, equating to $50 \mathrm{~m}$ for the upper and $70 \mathrm{~m}$ for the lower sediments.

Uncertainty in interval velocity estimates from refraction data $\sim 0.1 \mathrm{~km} / \mathrm{s}$ and $\sim 0.3 \mathrm{~cm} / \mathrm{ky}$ for sedimentation rates.

The interpreted seismic stratigraphy (Figs. 5B and 6B) at these points were drawn on the time-diagram and vertically stretched so that the basement age, as well as the ages of the upper two units obtained from the boreholes (Fig. 3), matched the time-scale. The relative time span for the deposition of each unit was estimated by projecting the first and last occurrence of each unit back into the time scale (colour bars, Fig. 8). Each colour matches the corresponding seismic stratigraphic unit in the representative sections. The age range for each unit was used in combination with the sediment thickness estimates (Fig. 7) to deduce the sedimentation rates (Fig. 9).

\section{Observations, results and interpretation}

\subsection{Basement ages}

The compiled magnetic spreading anomaly isochron map (Fig. 2; Table 2; online Supplement 1) constrained the basement ages as follows: Weddell Sea basin, 142.8-19.2 Ma (M17o-C6m); southwest Scotia Sea basin, 30.9-10.5 Ma (C12m-C5n.2 m); Powell Basin, 29.7-21.1 Ma (C11n.1o-C6AAo) and Jane basin, 17.4-14.4 Ma (C5Dn-C5ADn). The oldest magnetic anomalies occur in the southeast (Explora Escarpment), becoming younger towards the northwest part of the basin, near the Antarctic Peninsula. The lateral spreading age range for the Weddell Sea basement implies that sediments in contact with the basement should be younger than $124 \mathrm{Ma}$ in the southwest or $14 \mathrm{Ma}$ in the northwestern Weddell Sea. The magnetic isochrons crossing the WS-SS transect constrained the basement ages for the 13 selected points used to construct the age model (thin red lines in Fig. 2; red drop down lines in Figs. 5 and 6; listed ages below the 13 points in Fig. 8).

\subsection{Borehole correlation}

The WS-SS seismic transect seismic data matched the key stratigraphic boundaries in ODP leg 113 sites 693, 694 and 697 well (Fig. 2). The upper part of WS-S3 was constrained to an Eocene age (site 693), WS-S4 Oligocene to Miocene (site 693), WS-S5 late to middle Miocene (all sites), and WS-S6 and WS-S7 constrained to Pliocene and Pleistocene respectively for all sites (Fig. 2). Through the seismic tie lines, our interpreted units WS-S2 to WS-S7 correlated well to units identified in the SHALDRIL boreholes as well (Fig. 10).

\subsection{Seismic characterization and horizon stratigraphy}

Through the borehole stratigraphy (Fig. 3) and the reference type-section (Fig. 4), we traced continuous horizons across adjacent profiles along the $\sim 3300 \mathrm{~km}$ transect to produce a seamless correlation and a new stratigraphy (Figs. 5B and 6B). Two stratigraphic nomenclature models are proposed: The first is the nomenclature for the Weddell Sea, using the prefix WS and appended with " $S$ " for seismic stratigraphic unit (units WS-S1 to WS-S7) and " $u$ " to indicate the base reflection or horizon also referred to as an unconformity or discontinuity (WS-u1 to WS-u7 in Figs. 5B and 6B).

The second nomenclature is suggested for circum-Antarctic correlation of the pre-glacial to glacial components (PG, T and FG, numbered from bottom to top in Fig. 4). The second system allows the interpretation of additional units that can still be grouped under the appropriate PG, T or FG component for the construction of crossregional isopach grids, irrespective of the regional stratigraphy.

The acoustic basement topography near the Antarctic Peninsula is mostly rugged, ridges occur and some seamounts break through to 


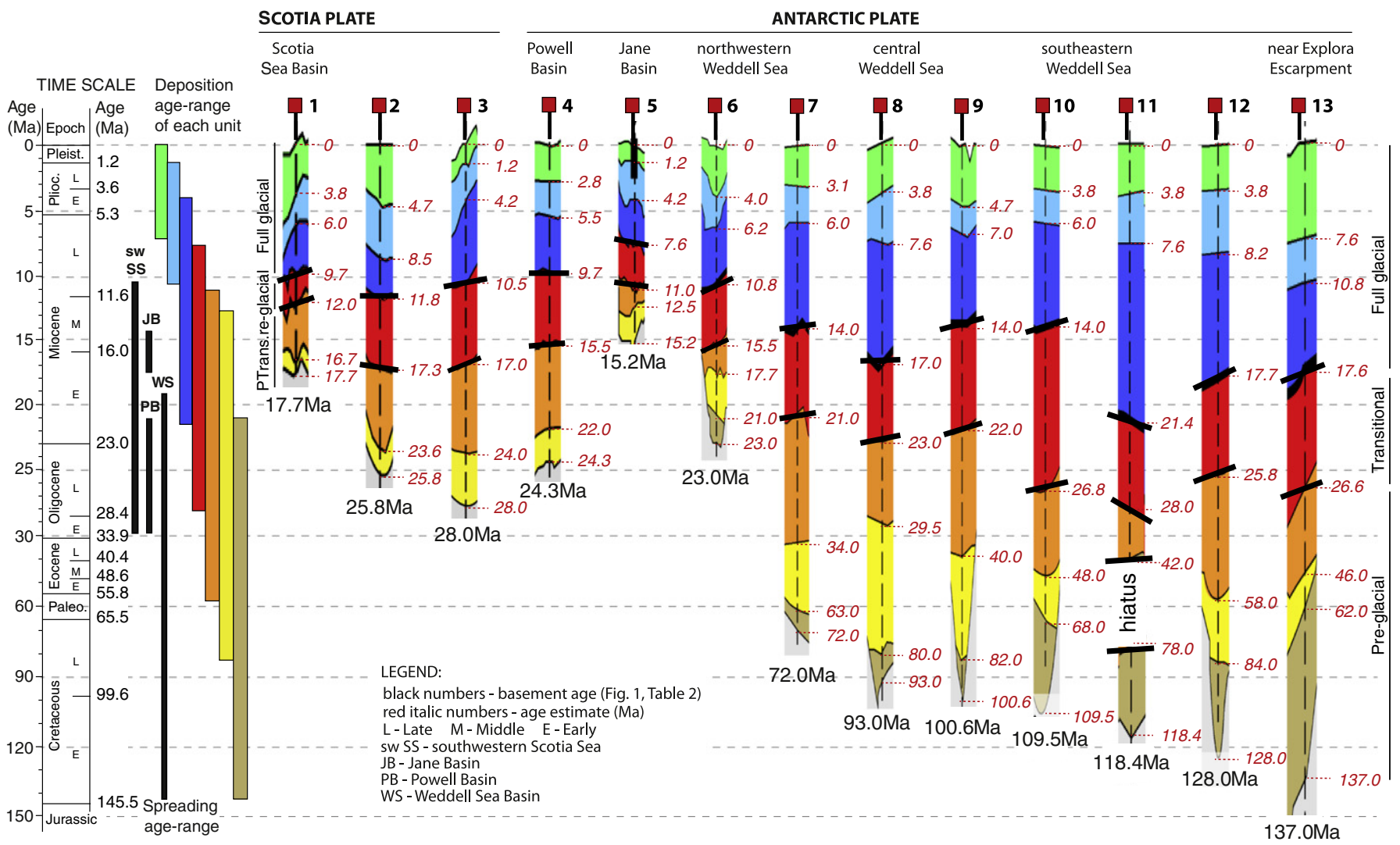

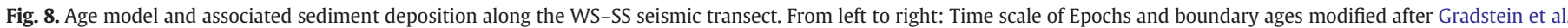

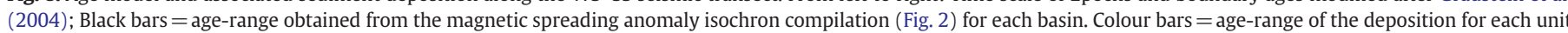

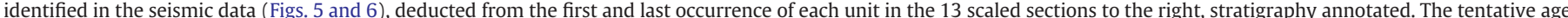

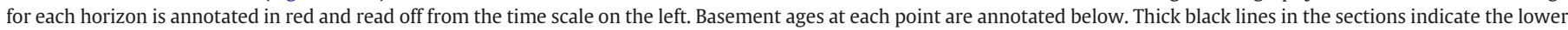
(uPG-T) and upper (uT-FG) boundaries of the pre-glacial to full glacial transitional unit. The vertical scale of the type sections represents time and not sediment thickness.

the seafloor (e.g. profiles SCAN04-17, M31 and M05 in Fig. 5A; northwestern most part of profile BAS845-15, Fig. 6A). The Weddell Sea basement topography is less rugged with smaller valleys, but lies more or less on the same average level. In the absence of deep boreholes, the interpretation of basement is based on the seismic reflection data. For clarity, faults were not interpreted. Our resulting acoustic basement horizon (WS-u1) compares well with the refraction data and derived crustal model of Rogenhagen and Jokat (2002).

The seismic reflectivity of units WS-S1 till WS-S7 (Figs. 5A and 6A) match those of each unit described in the type section (Fig. 4) very

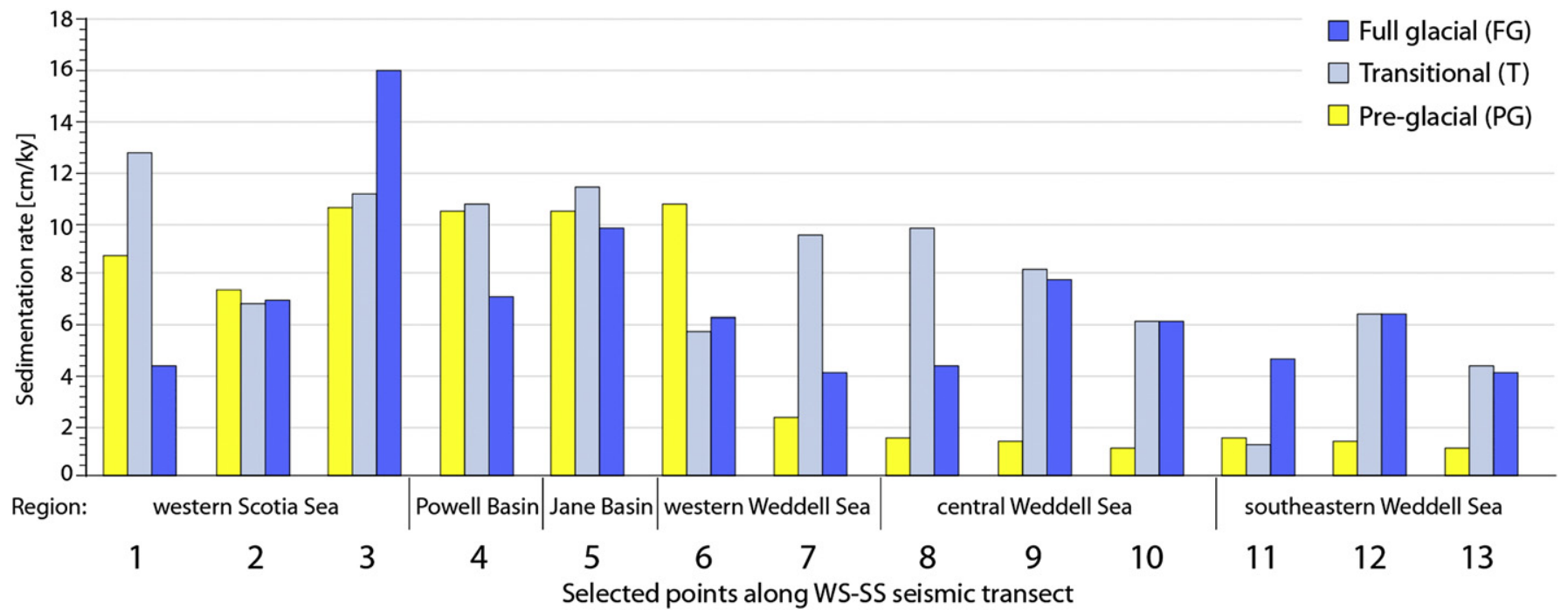

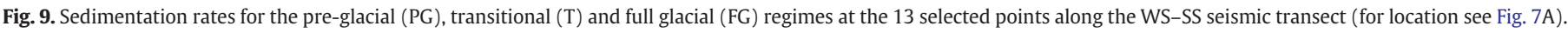

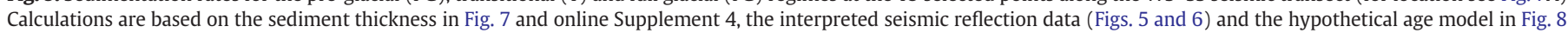
Rates are given in cm/ky and listed in Table 4 and online Supplement 5. 


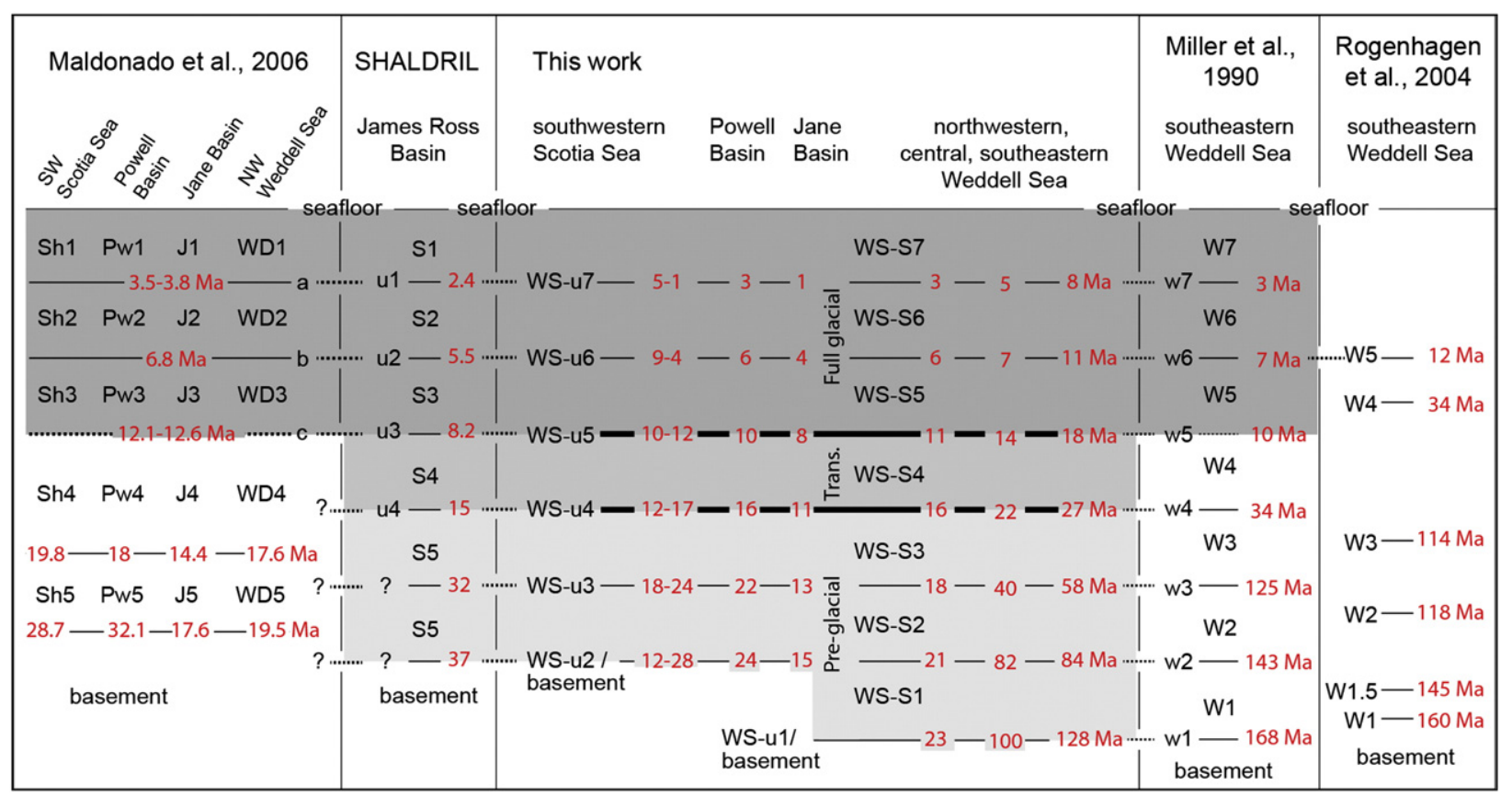

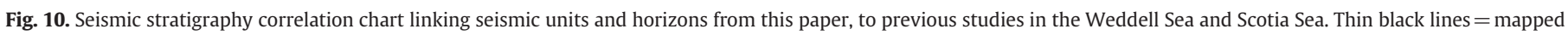

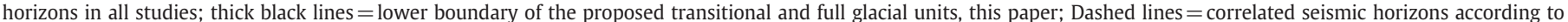

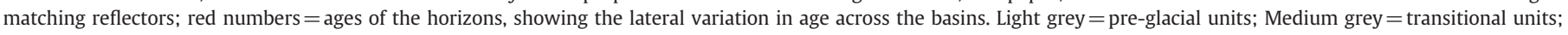
Dark grey $=$ full glacial units. SHALDRIL refers to Anderson (2006), Smith and Anderson (2010, 2011), Anderson and Wellner (2011), and Bohaty et al. (2011).

well and show negligible lateral variation between the northwestern and southeastern Weddell Sea, or the smaller Jane and Powell Basins. All units are laterally continuous and well stratified with reflectors that are mostly coherent, horizontal and undisturbed, and easy to trace over long distances. Layering is parallel to the seafloor except in the middle of the Weddell Sea basin where the older, lower amplitude units appear to form a mound. The mound is especially recognisable to the Southeast of borehole 694 in the seismic image (Fig. 6A).

The PG sequence WS-S1, WS-S2 and WS-S3, is bounded by the acoustic basement reflection WS-u1 below and reflector WS-u4 above (Fig. 6A; online Supplement 3). WS-u4 or uPG-T marks a prominent change in seismic facies from low amplitude, more transparent, laterally discontinuous reflectors in the sequence below, to more continuous, higher amplitude, parallel reflections in the sequence above (Figs. 5A and 6A; online Supplements 2 and 3).

The T sequence consists of one seismic unit, WS-S4 and is bounded by reflector WS-u4 below and WS-u5 above, alternately referred to as horizons uPG-T and uT-FG (Figs. 5 and 6). Although thinner seismic units can be distinguished within WS-S4, the seismic facies characteristics are similar and grouped as one unit here. WS-u5 was picked as the top boundary horizon for this sequence because in the seismic data we see the lower reflective T-unit package below this reflection, rapidly transitioning into a sequence of high amplitude, closely spaced, horizontal reflections above (Fig. 6A). It is a thick strong high amplitude reflection that could easily be traced across the basin and merge with several unconformities above, especially near the flanks of the basin (Fig. 6A and 11; online Supplement 3). We interpreted these seismic characteristics to represent the first sedimentary sequences transported down-slope and onto the abyssal plain via the first ice sheet advancements to the outer shelf.

The FG sequence consists of three seismic units, WS-S5, -S6 and -S7 and is bounded by horizon WS-u5, the T to FG period unconformity (uT-FG) below, and the seafloor reflection above (Fig. 6). We assume the change in seismic facies and more complex internal structures (e.g. drifts) represent change in depositional processes. Hence we interpret the sharp transition to represent the onset of the full glacial regime processes and transition to a modern polar ice sheet, consistent with observations around the Antarctic Peninsula (e.g. Diviacco et al., 2006; Rebesco et al., 2006; Rebesco and Camerlenghi, 2008).

The initial FG unit (WS-S5 or FG-1), drapes over this pre-glacial and transitional sequences mound and fills the basin low in the southeastern Weddell Sea (observed from point 10 to 13, Fig. 6). Thinner units WS-S6 and WS-S7 were deposited on the smoothed bathymetry as two horizontal bands of high amplitude finely laminated reflectors.

\subsection{Sediment thicknesses}

The lateral variations in sediment thickness are described for each unit in the Weddell Sea basin, from bottom to top and old to young, referring to Figs. 5 to 7 and online Supplement 4:

WS-S1 is absent in the Scotia Sea, Jane and Powell Basins, but continuous throughout the Weddell Sea basin (WSB). It increases in thickness from $282 \mathrm{~m}$ in the northwest (point 6, Fig. 7) to $545 \mathrm{~m}$ in the southeast at point 13 .

WS-S2 ranges from 273 to $640 \mathrm{~m}$ in the Scotia Sea (points 1-3), $395 \mathrm{~m}$ in the Powell Basin (point 4) and $247 \mathrm{~m}$ in the Jane basin (point 5). An interesting trend is seen in the Weddell Sea basin, where WS-S2 is thickest in the centre ( $474 \mathrm{~m}$ at point 9 to $302 \mathrm{~m}$ at point 7) and thinner on both flanks (266 $\mathrm{m}$ at point 6 and 285-293 $\mathrm{m}$ at points 12 and 13, Fig. 7). Notably WS-S2 is absent at point 11 .

WS-S3 is continuous along the entire transect and becomes thicker from the northwest to the southeast: $224 \mathrm{~m}$ thick at point 1 and thickening to $532 \mathrm{~m}$ at point 3 in the Scotia Sea, $524 \mathrm{~m}$ in the Powel basin, thinnest in the Jane basin $(139 \mathrm{~m})$ and ranges from 255 to $778 \mathrm{~m}$ (points 6 to 12, Fig. 7) in the Weddell Sea basin.

Collectively, WS-S1, WS-S2 and WS-S3 comprise the pre-glacial (PG) sequence, which ranges in total thickness from 441 to $1481 \mathrm{~m}$ (Table 4). A westward thickening of PG sediments was expected in the Weddell Sea basin, but instead we found a higher mound in the 
A) AWI-97010, after Rogenhagen et al. (2004)

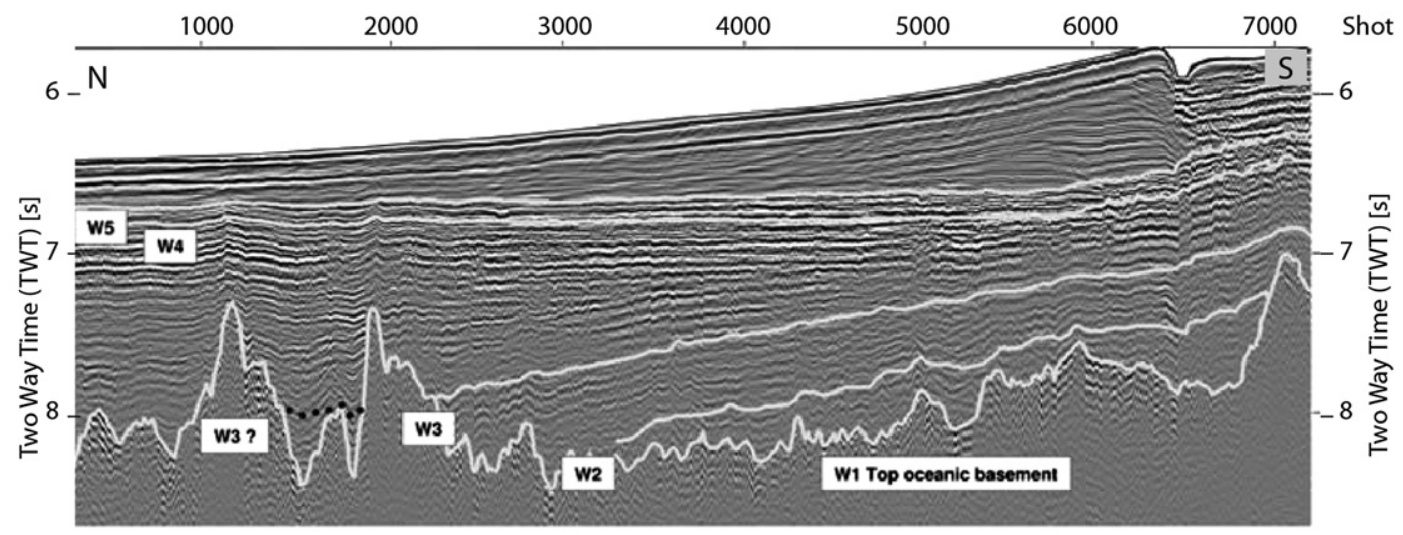

B) AWI-97010, this study

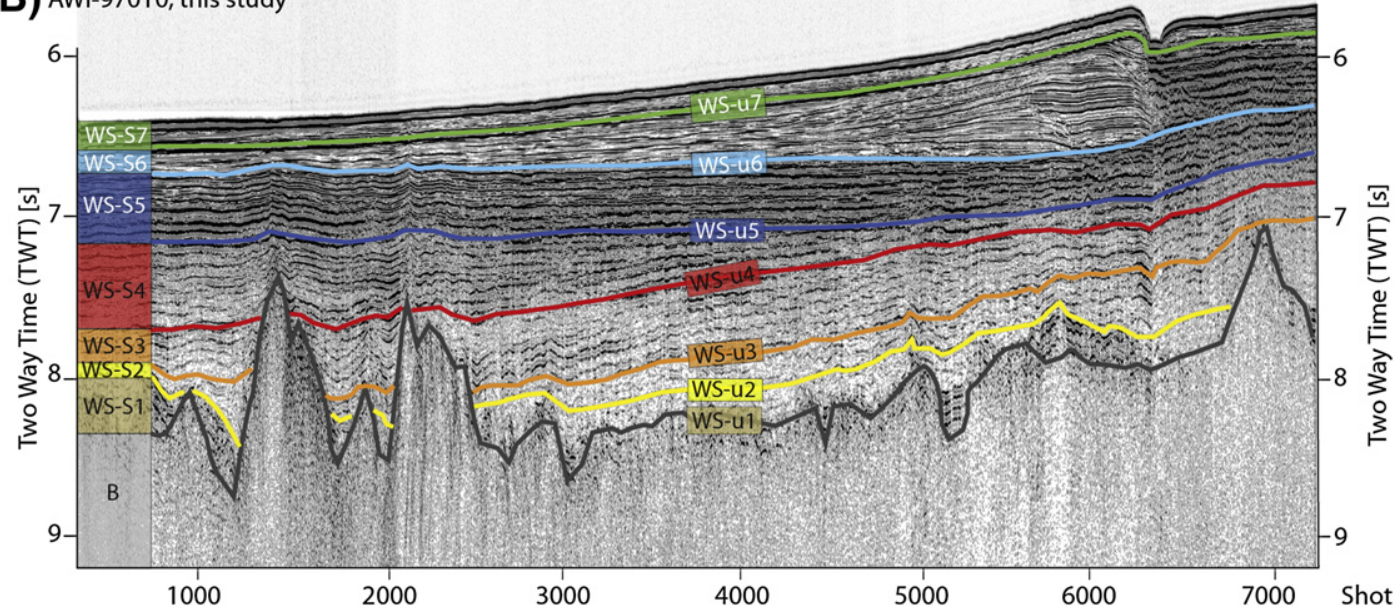

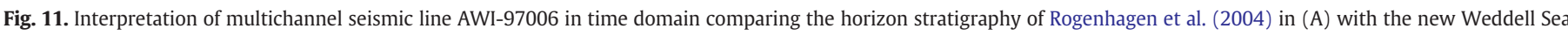

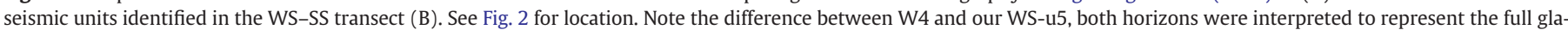

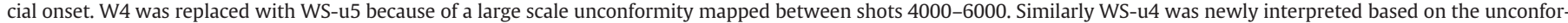

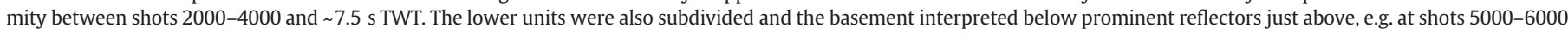
and $\sim 8 \mathrm{~s}$ TWT.

middle (between points 7 and 10 in Fig. 6B) flanked by a deeper basin in the southeast (points 10 to 13 in Fig. 6B) and a thicker part near the continental slope at the Explora Escarpment.

WS-S4 or the transitional unit (T-1) varies in thickness throughout the Scotia Sea and Weddell Sea (red band in Figs. 6 and 7). The thinnest part is observed at point $6(267 \mathrm{~m})$ and the thickest part at point $10(780 \mathrm{~m})$ in the northwestern Weddell Sea (Table 4). WS-S4 seems to have partly filled in the palaeo basin low in the southeast (points 7 to 13) and thins over the mound.

WS-S5 is the most prominent and the first full glacial sequence (dark blue unit in Figs. 5B and 6B). It is laterally massive, thick and continuous. Similar to WS-S1 to WS-S4, WS-S5 thickens towards the Antarctic Peninsula shelf in the Scotia Sea (185-851 m from points 1 to 3 ). The thickness of WS-S5 is relatively constant in the northwestern Weddell Sea (280-398 m), but thickens to $974 \mathrm{~m}$ in the southeastern Weddell Sea (point 11) and filled the remaining palaeo basin low (points 9 to 13 in Fig. 7, online Supplement 5). WS-S5 seemed to mostly smooth out the Weddell Sea pre-glacial to transitional mound-and-flanking basin palaeotopography.

WS-S6 is 122-208 m thick across the Weddell Sea and 140-560 m thick in the Scotia Sea, following the same trend as units WS-S2 to WS-S5. The thickest parts occur in the centre of the Weddell Sea where it drapes over the mound (point 9, $209 \mathrm{~m}$ ) and at either flank near the shelf ( $186 \mathrm{~m}$ at point 13 and $170 \mathrm{~m}$ at point 5; Fig. 7; online
Supplement 4). WS-S7 is the thinnest unit in the entire sedimentary sequence and shows little lateral variation in sediment thickness between the Scotia Sea (103-273 m) and Weddell Sea basin (126-215 m). Units WS-S5, WS-S6 and WS-S7 comprise the fully developed glacial (FG) sequence, which ranges in total thickness from 428 to $1684 \mathrm{~m}$ in the Scotia Sea and 583-1248 $\mathrm{m}$ in the Weddell Sea (Table 4; Fig. 7).

The total sediment thickness in the Scotia Sea ranges from 1218 to $3762 \mathrm{~m}$, and in the Weddell Sea from 1745 to $3123 \mathrm{~m}$ (Table 4). We estimate the deep-sea Weddell basin to have a minimum area of $\sim 1.3 \times 10^{6} \mathrm{~km}^{2}$ and a maximum area of $\sim 1.5 \times 10^{6} \mathrm{~km}^{2}$ (red outline in Fig. 1 inset). The shelf areas are not incorporated due to lack of data in front of the Filchner-Ronne Ice shelf. Taking an average sediment thickness of $\sim 2.5 \mathrm{~km}$ (Table 4 ) a first order minimum estimate of the total sediment volume for Weddell deep-sea basin would be $3.3 \times 10^{6} \mathrm{~km}^{3}$ and a conservative maximum volume estimate $3.9 \times 10^{6} \mathrm{~km}^{3}$. Under the assumption that the pre-glacial to fully glacial units occur throughout the Weddell Sea basin, we use the average thickness of each component $(P G=923 \mathrm{~m}, \mathrm{~T}=478 \mathrm{~m}, \mathrm{FG}=769 \mathrm{~m}$; Table 4) and the minimum and maximum basin area to estimate sediment volumes. Minimum volumes are: $\mathrm{PG}=1.2 \times 10^{6} \mathrm{~km}^{3}, \mathrm{~T}=$ $0.6 \times 10^{6} \mathrm{~km}^{3}$ and $\mathrm{FG}=1.0 \times 10^{6} \mathrm{~km}^{3}$ and the conservative maximum volumes: $P G=1.4 \times 10^{6} \mathrm{~km}^{3}, \mathrm{~T}=0.7 \times 10^{6} \mathrm{~km}^{3}$ and $\mathrm{FG}=$ $1.2 \times 10^{6} \mathrm{~km}^{3}$. 


\subsection{Age model}

In our age model Weddell Sea basement age is estimated at $137 \mathrm{Ma}$ in the southeastern part of the transect and becomes progressively younger ( $23 \mathrm{Ma}$ ) towards the northwest (Fig. 8). WS-S1 has the largest age range of all the units. In the southeast near the Explora Escarpment it is 137-62 Ma at point 13 and 23 Ma in the northwest (point 6 in Fig. 8). Units WS-S2 and WS-S3 both follow a similar trend as WS-S1 and become younger to the northwest as well (84.0-17.7 Ma and 58.0-15.5 Ma at points 13 to 6, Fig. 8). A hiatus of $~ 36$ Ma occurs at point 11 where unit WS-S2 is absent, probably due to erosion. The lower boundary of the transitional unit (horizon WS-u4 or uPG-T) decreases in age from 26.8 Ma in the southeastern Weddell Sea (point 13 in Fig. 8) and to $15.5 \mathrm{Ma}$ in the northwestern Weddell Sea (point 6), being slightly younger in the Jane basin (11 Ma). The uPG-T horizon shows lateral age variation in the Scotia Sea of 17.3-12.0 Ma, the oldest part near the Antarctic Peninsula and becoming younger to the northwest (points 1-3, Fig. 8).

The upper boundary of the transitional unit (horizon WS-u5 or uT-FG), interpreted to represent the advancing ice sheets grounding on the outer shelf for long periods in a full glacial regime, also youngs from southeast to northwest (17.7-10.8 Ma at points 13 to 6, Fig. 8). We observe an older outlier age of $\sim 26.8 \mathrm{Ma}$ at point 11 in the Weddell Sea basin and a younger age of $\sim 7.6 \mathrm{Ma}$ at point 5 in the Jane Basin. Horizon WS-u6 has a tentative age of $\sim 10.6 \mathrm{Ma}$ in the southeastern Weddell Sea basin (point 13) and becomes increasingly younger up to $6.0 \mathrm{Ma}$ in the northwest (point 7, Fig. 8). The model age of $\sim 7.6 \mathrm{Ma}$ at point 11 for WS-u6 fits with the regional trend. Horizon WS-u7 shows a modelled lateral age variation of $\sim 3.8-1.2 \mathrm{Ma}$ (points 1 to 4 , Fig. 8 ).

\subsection{Sedimentation rates}

The age model was used in combination with the derived sediment thickness estimates (Fig. 7; Table 4) to deduce sedimentation rates for the pre-glacial, transitional and full glacial components of the deep-sea sediment archive in the Weddell Sea basin (Table 4; Fig. 9). Since there are uncertainties in our age model due to the absence of borehole age-control, we only comment the sedimentation rate trends. The pre-glacial sedimentation rates at points 4-6 in the Powell Basin, Jane Basin and northwestern Weddell Sea are the highest (10-11 cm/ky, Table 4; yellow bars in Fig. 9) and almost an order of magnitude higher than the rates in the central Weddell Sea $(1.1-1.6 \mathrm{~cm} / \mathrm{ky})$. Although the Weddell Sea pre-glacial units are the thickest (894-1481 m), the sedimentation rates are the lowest.

The transitional sedimentation rates range from 1 to $10 \mathrm{~cm} / \mathrm{ky}$ in the Weddell Sea and 7-13 cm/ky in the Scotia Sea (Table 4; middle bars in Fig. 9) and are almost an order of magnitude higher than the pre-glacial rates. An anomalous transitional sedimentation rate of $1.2 \mathrm{~cm} / \mathrm{ky}$ occurs at point 11 , the same place where the hiatus and eroded WS-S2 unit are observed (Fig. 8). In the central and northwestern Weddell Sea the transitional sedimentation rates are amongst the highest $(8-10 \mathrm{~cm} / \mathrm{ky})$. Higher transitional sedimentation rates occur on the flanks of the Weddell Sea basin as expected (points 7-9 and 12; Fig. 9; Table 4) since it is closer to sediment supply from land.

The full glacial sedimentation rates are the highest at points 3 and 5 in the Scotia Sea and Jane Basin $(\sim 16 \mathrm{~cm} / \mathrm{ky}$ and $10 \mathrm{~cm} / \mathrm{ky})$ and at points 9 and 11 in the Weddell Sea ( 7-8 cm/ky, Fig. 9; Table 4).

\section{Discussion}

The new basin-wide seismic stratigraphy and assignment of seismic units to PG, T or FG components rest on the basic premise that glacial sediment input and transport is recorded in the seismic strata. Based on our age model, the seven identified horizons increase in age from the southeastern to the northwestern Weddell Sea. This result is different from local scale studies where a uniform age for each horizon is often assumed (Miller et al., 1990; Rogenhagen et al., 2004; Maldonado et al., 2006). For the pre-glacial units this lateralincrease-in-age trend can be ascribed to sediments being deposited synchronous to seafloor spreading and formation of the Weddell Sea basin. However, in the transitional and full glacial units it is presumed to represent the lateral increase in sediment supply and consequential increase in down-slope and along-slope sediment transport processes. Such increases are often related to ice sheet advance and intensification of bottom currents. We compare our findings to previous work and discuss our observations in the context of implications for understanding the bottom water ocean circulation changes and ice sheet development in the pre-glacial to glacial climate transition.

\subsection{Pre-glacial $(P G)$ regime}

Previous seismic stratigraphy work in the Scotia Sea, the Powell and Jane Basins, and in the northwestern Weddell Sea identified two pre-glacial seismic units assigned to Oligocene-early Miocene age (e.g. Sh5, Sh4; Pw5, Pw4; J5, J4; WD5, WD4 in Fig. 10). We identified additional prominent horizontal reflections in the central Weddell Sea (profile BAS645-15, Fig. 6) and upon tracing them as well as boundary horizon WS-u4 into the northwestern Weddell Sea, Powell and Jane Basins and southern Scotia Sea, found that they mismatched this previous work (Fig. 10). We consequently re-divided the PG seismic sequence into three units instead of the previous two, labelled bottom up as WS-S1, WS-S2 and WS-S3 (Figs. 6 and 10). These boundary horizons of these units (WS-u1, WS-u2, WS-u3) were traced farther into the southeastern Weddell Sea and matched all horizons in the seismic stratigraphy of Miller et al., 1990 (Fig. 10), but disagree with seismic stratigraphy model of Rogenhagen et al. (2004). Contrary to Rogenhagen et al. (2004), we re-interpret the basement reflector WS-u1 up to $0.5 \mathrm{~s}$ deeper, below the series of strong horizontal reflectors directly above basement (Figs. 10 and 11). This was done because in our opinion these could either be older consolidated sediments or lava flows, especially considering that the thickest part lies near the Explora Escarpment.

Horizons WS-u2 and WS-u3 matched the seismic stratigraphy of SHALDRIL and Maldonado et al. (2006) in the northwestern Weddell Sea (Fig. 10). These two horizons were farther traced across the central Weddell Sea and into the southeastern part of the basin, where it mismatched horizons W2 and W3 in Rogenhagen et al. (2004) and we interpreted at different positions based the cross-basin correlation in continuous data and on observed unconformities (Figs. 10 and 11).

The PG horizons all show a lateral variation in age in the southern Scotia Sea, Jane and Powell Basins, northwestern and southeastern Weddell Sea (Fig. 10) and our age range compares well to previous tentative age estimates (Figs. 8 and 10; Maldonado et al., 2006; Miller et al., 1990). The PG ages in the northwestern Weddell Sea (Figs. 8 and 10) are consistent with late Oligocene pre-glacial strata ( 28.4-23.3 Ma) drilled in SHALDRIL Hole 3C (Bohaty et al., 2011; Fig. 3).

The southeastern Weddell Sea basement is the oldest (up to 145 Ma, M17; Fig. 1; Table 2) and nearest to the shelf at Dronning Maud Land. We would therefore expect to find the thickest sediments and highest sedimentation rates on the slope near this continental margin. Instead, we found a $\sim 1130$ m thick mound in the centre of the Weddell Sea basin on much younger basement (93-45 Ma, Figs. 1 and 6; Tables 2 and 4). The depositional geometry on both the northwestern and southeastern flanks of the mound has a basin shape (Figs. 6 and 12A). If the basin-like depressions were due to differential compaction, the reflectors would be offset or curved in the seismic image, but this is not observed. It also leaves the thinner units $(<790 \mathrm{~m})$ to the east of the mound and the partial absence of unit WS-S2 at point 11 unaccounted for.

We consider alternative processes that may cause high sediment transport to the deep-sea. A typical mechanism is ice rafting and ice 


\section{A) CRETACEOUS - PALEOCENE}
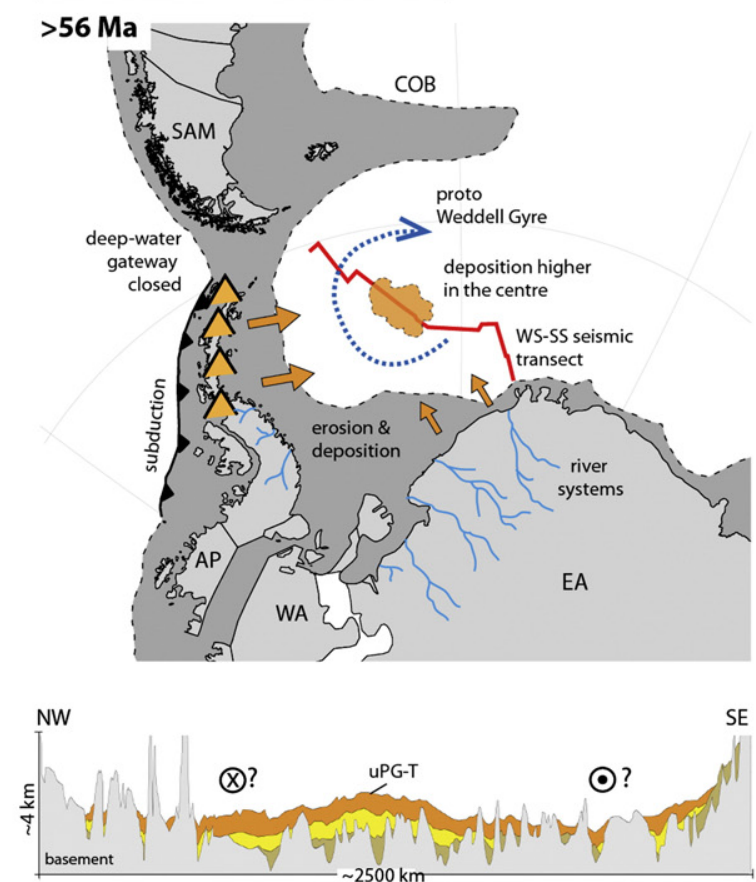

Pre-glacial regime units

Weddell Sea basin part of the transect

\section{C) MID-MIOCENE}
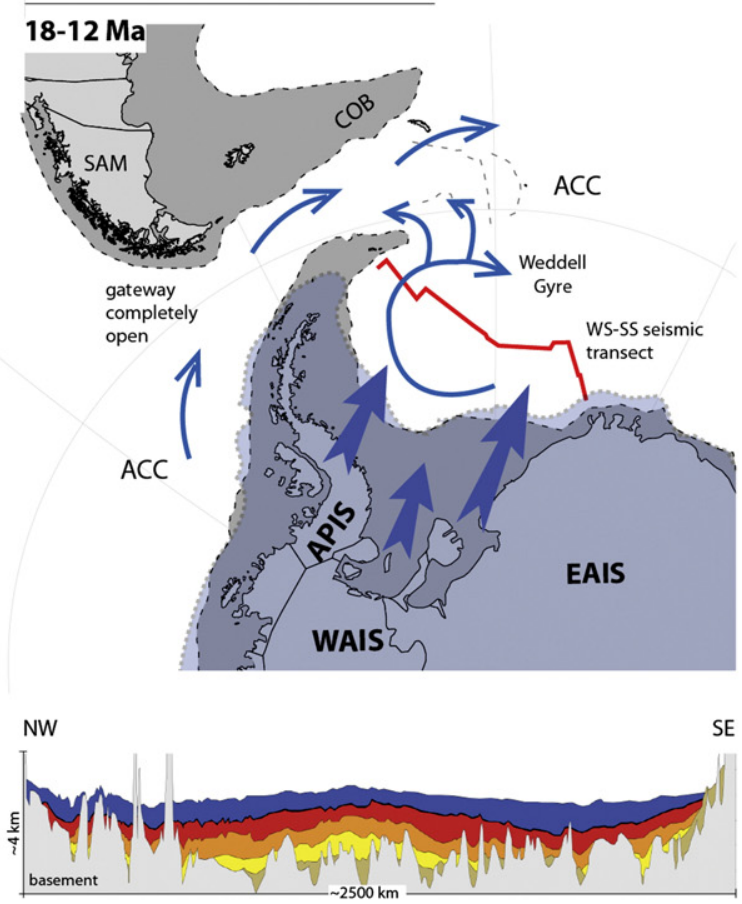

Full glacial units
B) EOCENE - OLIGOCENE
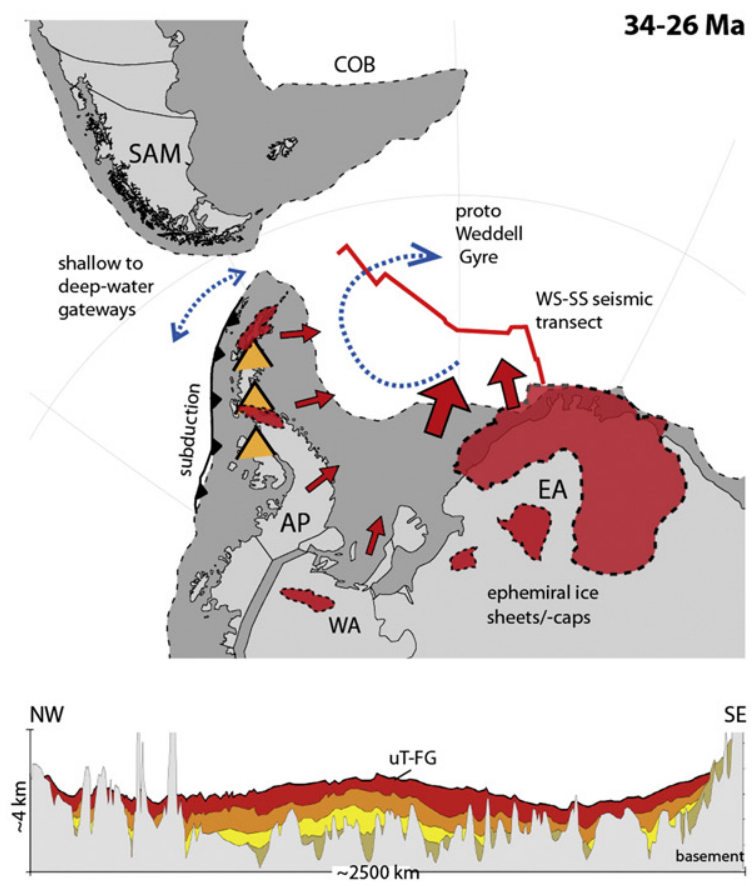

Transitional regime units

D) QUATERNARY
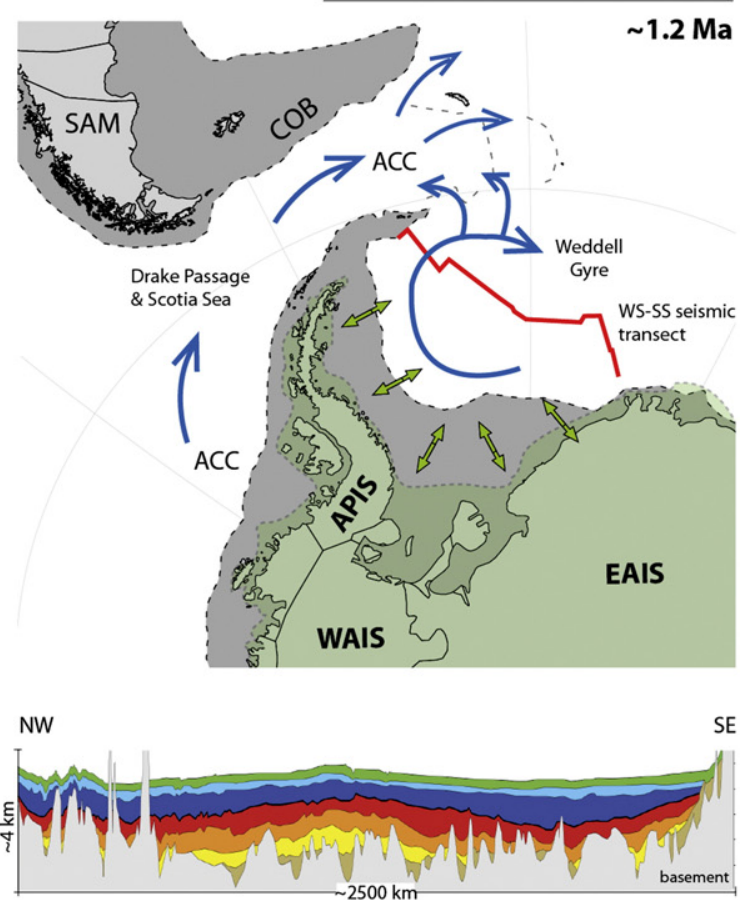

Full glacial regime units continued.

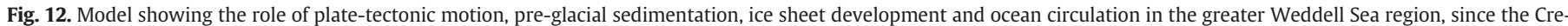

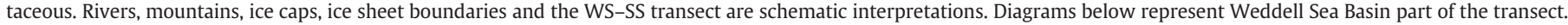

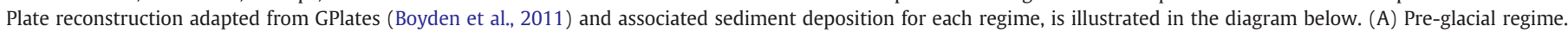

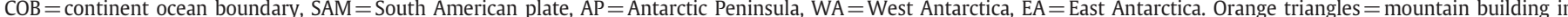

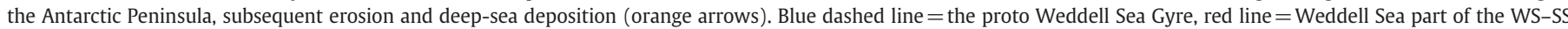

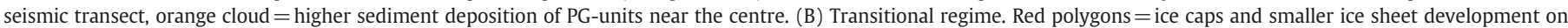

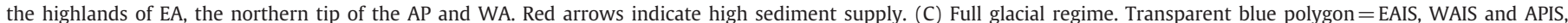

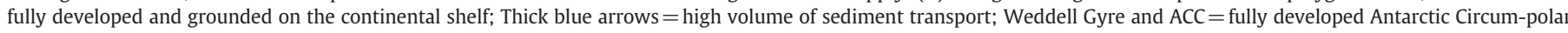

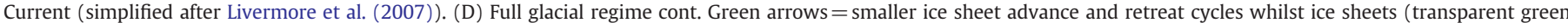
polygon) still remain grounded on the outer shelf. 
sheets pushing sediments onto the slope and rise as they ground on the outer shelf. However, given the warm climate and ice minimum conditions (Zachos et al., 2001) inferred for the Cretaceous-Eocene pre-glacial seismic sequence, mass sediment transport due to expanding ice sheets becomes an unlikely process and we have to consider other explanations. High bio-productivity and mortality could cause high pelagic fall-out and could account for high sediment supply in the deep-sea, but fail to explain the mound and basin-like depressions. Tectonic uplift and an underlying basement high or low are also excluded because, although the Weddell Sea basement is highly variable and uneven (Fig. 6) when averaged, it remains on a similar level.

Thinner units ( $<790 \mathrm{~m}$ ) to the east of the mound (Fig. 6 and 12A), the partial absence of unit WS-S2 and the anomalously low transitional sedimentation rate of $1.2 \mathrm{~cm} / \mathrm{ky}$ at point 11 (Figs. 6 and 8), collectively allow the interpretation that bottom current erosion may have caused this mound-basin depositional geometry. Such bottom currents could have been caused by down-slope sediment influx from the Crary Fan (Kuvaas and Kristoffersen, 1991; Bart et al., 1999; Michels et al., 2001, 2002) or a Cretaceous-Eocene proto-Weddell Gyre that build the mound in the centre whilst eroding the flanks asymmetrically. We consider it unlikely that the Crary Fan downslope current could solely account for the mound-basin geometry for the following reasons: Michels et al. $(2001,2002)$ observed combined contourite-turbidite sedimentation patterns at the western and southeastern Weddell Sea margin (south of $70^{\circ} \mathrm{S}$ ) for the transitional (W4) and full glacial sequences (their regional unconformity W5). Pre-glacial sediments were not considered in their study. Of the three identified main Crary Fan down-slope channels, each about 2-5 km wide, two could perhaps be interpreted in the WS-SS transect between points 8 and 9 (black arrows Fig. 6). However, these are at least two orders of magnitude smaller than the basin-wide features observed in the transect, unpronounced and constrained to uppermost the Pliocene-present day layers. Additionally the WS-SS transect is more than $500 \mathrm{~km}$ (or $5^{\circ}$ ) north from the slope and Crary Fan extent (Kuvaas and Kristoffersen, 1991; Bart et al., 1999; Michels et al., 2001, 2002). We thus favour the proposed proto-Weddell Gyre hypothesis as the most likely dominant process responsible for the depositional geometry.

The fact that the depression is deeper and the units thinner on the southeastern flank than on the northwestern flank, may be consistent with the up-current side and hence with a clockwise circulation (Fig. 12A). To our knowledge a proto-Weddell Gyre has not been proposed before, but Eocene-Oligocene proto-Antarctic Bottom Water and Weddell Sea Deep Water masses has been inferred for preglacial regimes at Maud Rise, from $\delta^{18} \mathrm{O}$, mineral and grain analyses in ODP leg 113 site 690 (Diester-Haass. et al., 1996).

Contourites were used to determine bottom current direction around the Antarctic Peninsula for transitional and full glacial deposits (e.g. Maldonado et al., 2005; Uenzelmann-Neben, 2006). Although typical contourite drift structures are not clearly observed in the WS-SS transect seismic data, the seismic profiles are too sparse to exclude their existence in the pre-glacial central Weddell deep-sea units. Further analyses of the two parallel transects (A and C in Fig. 1) are ongoing and might shed more light on the proto-gyre circulation direction. The driving force of the proto-gyre circulation remains unclear as well. The ACC is not fully developed because South America was still connected to Antarctica with shallow water gateways (Fig. 12A; Livermore et al., 2007), but Weddell Bottom Water could have formed due to sea ice. Either way, the mound feature is prominent enough that it warrants future investigation.

\subsection{Transitional $(T)$ regime}

The base reflector of the transitional unit, WS-u5, was traced from the northwestern Weddell Sea into the Jane Basin, Powell Basin and the Scotia Sea, where it exactly matched with horizon "c" of Maldonado et al. (2006; Fig. 10). Based on seismic facies changes and downlap terminations, they postulated that horizon "c" represents an erosional surface signalling the incursion of bottom water exchange between the Scotia and Weddell Sea and coeval to the Mi4 glaciation. WS-u5 and WS-u4 partially correlates to S3 ( 8 Ma) in the SHALDRIL boreholes identified as the start of the PG to FG transitional sequence at the Antarctic Peninsula (Fig. 3; Smith and Anderson, 2010, 2011; Bohaty et al., 2011).

Our model age of $\sim 17.6 \mathrm{Ma}$ (point 13 in Fig. 8) is also consistent with the ODP leg 113 site 693 borehole age of early mid-MioceneLate Miocene of 16-11 Ma (Figs. 3 and 10). Tracing WS-u5 into the southeastern Weddell Sea it matched horizon w5 of Miller et al. (1990) but mismatched the W4 marker horizon (Rogenhagen et al., 2004) that represents the onset of the FG regime in the deep-sea (Figs. 10 and 11). We re-interpret W4 of Rogenhagen et al. (2004) in the southeastern Weddell Sea and place it $\sim 0.75 \mathrm{~s}$ deeper (WS-u5, dark blue line in Fig. 11).

Which depositional processes active in the Eocene-Oligocene transitional climate associated with high sediment transport may have formed this WS-S4 unit? Previous seismic stratigraphy studies postulated that ephemeral ice caps and small ice sheets formed on high elevations in the West Antarctica, with the EAIS periodically grounding on parts the outer shelf and increasing sediment supply to the deep-sea (e.g. Miller et al., 1990; Oszko, 1997; red polygons and arrows in Fig. 12B). Isolated gravel and terrigenous sand grains in ODP leg 113 site 689 and 690 at Maud Rise, offshore north of Dronning Maud Land, provided evidence for a grounded Eocene EAIS since $\sim 45.5 \mathrm{Ma}$, probably with a more temperate rather than polar character (e.g. Ehrmann and Mackensen, 1992).

If it is the case that only the EAIS grounded during the EoceneOligocene, the highest sediment supply would presumably be in front of the Crary Fan and on the slope and rise of the southeastern Weddell Sea near the Explora Escarpment (Fig. 1), with little or no ice sheet related sediment supply at the Antarctic Peninsula. The effect would be transitional deposits that are thicker in the southeast than in the northwestern part of the Weddell Sea basin and the Antarctic Peninsula. On the contrary, we observe that unit WS-S4 is thickest in the northwestern Weddell Sea $(<806 \mathrm{~m}), 400-600 \mathrm{~m}$ thick in the central and southeastern Weddell Sea and thinnest over the peak of the mound ( 383 m; Fig. 7; Table 4; online Supplement 5). WS-S4 drapes over the mound and partly fills in the basin depressions to either side, whilst being continuous along the entire WS-SS transect and probably basin-wide (Fig. 6; online Supplement 3).

It is likely that bottom current processes could have redistributed sediments from the southeastern EAIS source region to the central and northwestern Weddell Sea, thus maintaining the eroded basin geometry to the east of the mound. The transitional unit displays no along-slope drift or contourite structures but was interpreted as a sheeted drift. Bottom current processes alone cannot account for the WS-S4 geometry. The continuous occurrence and thicker WS-S4 deposits in the northwestern Weddell Sea can also be explained by along-slope sediment supply from the proto- Weddell Gyre circulation, down-slope supply by an advancing ephemeral EAIS, and from advancing ice sheets in the North-West i.e. WAIS and the southern APIS.

SHALDRIL boreholes and seismic records on the southern margin of the Joinville Plateau show glacial marine sedimentary processes dominated sedimentation since the late Oligocene and a phased APIS expansion from south to north across the Peninsula in the late Miocene (e.g. Smith and Anderson, 2010, 2011; Bohaty et al., 2011) or Oligocene (Davies et al., 2012). High transitional sedimentation rates around the Antarctic Peninsula $(11 \mathrm{~cm} / \mathrm{ky})$ and northwestern Weddell Sea (6-10 cm/ky; Fig. 9; Table 4) and the age variation of the initial ice grounding boundary horizon, uPG-T (27-16 Ma; WS-u4 in Fig. 10) across the Weddell Sea, allow the interpretation that the southern 
part of the APIS probably already grounded in the early Miocene or even Oligocene, and the WAIS in the Oligocene. Sampling, drilling and multichannel seismic reflection data analyses of Drift 7 on the Pacific margin of the Peninsula, suggest down-slope transport as a result of the growth of the Antarctic Peninsula ice sheet in the Early Miocene ( 15 Ma and 9.5 Ma; Uenzelmann-Neben, 2006). This early Miocene/ Oligocene APIS and Oligocene WAIS expansion is not adequately reproduced by palaeoclimate models that suggested a late Mioceneearly Pliocene APIS grounding (7.94-5.12 Ma, Bart et al., 2005; Pollard and DeConto, 2009; Table 1), but consistent with the SHALDRIL findings (Anderson et al., 2011).

\subsection{Full glacial (FG) regime}

In the Scotia Sea, Jane Basin, Powell Basin and northwestern Weddell Sea, seismic horizons WS-u5, -u6 and -u7 identified in this study match the horizons "c", "b" and "a" of Maldonado et al. (2006; Fig. 10). Our interpreted horizons show a lateral age variation contrasting the uniform ages assigned in Maldonado et al. (2006; Fig. 10). Seismic units WS-S5, WS-S6 and WS-S7, listed from old to young, consistently matched the upper three units in the southern Scotia Sea (Sh3-Sh1), Powell Basin (Pw3-Pw1), Jane Basin (J3-J1) and northwestern Weddell Sea (WD3-WD1) mapped in previous studies (Fig. 10). Horizon WS-u6's age of $\sim 5.5 \mathrm{Ma}$ in the Powell Basin (Figs. 8 and 10) is in broad agreement with the base-age of S2 ( $5.5 \mathrm{Ma}$ ) dated in the nearby SHALDRIL cores, even though the latter lies on the shelf (Fig. 10; Smith and Anderson, 2010; Bohaty et al., 2011). WS-u7 is correlated to reflector "a" in Maldonado et al. (2006) dated in their study at 3.5-3.8 Ma from ODP leg 113 site 695-697 (see Fig. 2 for borehole locations). Our age range 3.8-1.2 Ma is also in good agreement to the base-age of S1 (2.4 Ma) in the SHALDRIL cores (Fig. 10; Smith and Anderson, 2010; Bohaty et al., 2011).

In the southeastern Weddell Sea, horizons WS-u6 and WS-u7 matched horizons w6 and w7 of Miller et al. (1990), dated at late Miocene $(\sim 7 \mathrm{Ma})$ and late Pliocene $(\sim 3 \mathrm{Ma})$ in ODP leg 113 sites 692 and 693 (Figs. 2C and 10). Horizon WS-u6 is correlated with horizon W5 of Rogenhagen et al. (2004) and our tentative model age of 10.8-8.2 Ma for the southeastern Weddell Sea broadly agrees with their older extrapolated age of $\sim 12 \mathrm{Ma}$ (Figs. 10 and 11). Horizon WS-u7 was absent in the Rogenhagen et al. (2004) model and is newly interpreted on the AWI-97 profiles (Figs. 6 and 11; Table 3) to match horizons traced from ODP leg 113 site 694 (Fig. 3).

Taking into account the geometry, lateral variation in sediment thickness and sedimentation rates of the transitional unit along the WS-SS transect, we infer from our observations which depositional processes in the Miocene-Quaternary may have played a role in the deposition of these units. WS-S5 filled the basin lows on either side of the inferred mound and levelled the basin bathymetry (dark blue unit, Figs. 6 and 12C). If the mound formed in response to an assumed proto-Weddell Gyre that intensified in the Miocene glacial regime, it poses the question of why the full-glacial units do not reflect mound geometry as well.

Reason for this change in geometry could be that the Weddell Gyre erosion capacity changed due to the development of the ACC (Table 1; Fig. 12C) or that the glacial/ice sheet till particles became too large to be transported by bottom currents over long distances. Sediments created by glacial process would have larger grain sizes, thus be heavier and require more energy to transport than pelagic fall-out. We consider it most likely that sedimentation rates were much higher than the erosion rate due to increased sediment supply and deposition to the deep-sea. Even after full glacial conditions were developed on the continent, there were still significant volumes of fine sediments being produced and deposited around the continent. It is generally observed that sedimentation rates increased during the early phases of glaciation, which is expected.
ODP Site 697 in Jane Basin reported a sedimentation rate of $4.4 \mathrm{~cm} / \mathrm{ky}$ for the upper $200 \mathrm{~m}$, increasing down core to $10 \mathrm{~cm} / \mathrm{ky}$ for the interval of 250-300 m (Barker et al., 1988; Gersonde et al., 1990; Ramsay and Baldauf, 1990). Our estimated rate of $9.9 \mathrm{~cm} / \mathrm{ky}$ for the full glacial unit ( 749 m thick) in the Jane Basin compares extremely well to the ODP rates and to $10 \mathrm{~cm} / \mathrm{ky}$ reported in Maldonado et al. (2006).

Sediment transport by expanding ice sheets is the most probable process capable of rapidly eroding sediments on land and the continental shelf, transporting it to the outer shelf and as the ice sheets grounded, pushed massive volumes of sediments over the edge in a bulldoze effect. Such increased supply to the deep-sea would balanced the gyre or bottom current erosion and result in a smoothed out basin geometry. An alternative interpretation, although speculative, is that the proto-Weddell Gyre was constrained during its initial development to the margins of the basin and flowed mostly as a density nepheloid layer. The particles that escaped from this nepheloid layer were deposited in the central basin plain.

ODP leg 113 site 694 lies in the central Weddell Sea and on profile BAS845-15 of the WS-SS transect (Fig. 2). The matched seismic stratigraphy of this borehole and our transect (Fig 3), constrained unit WS-S5 and reflectors WS-u5, WS-u6 to middle-late Miocene age in our age model (Fig. 8). The borehole log also reported glacial turbidite units and present evidence of deep-sea glacial sediment transport during this time, implying that grounded ice sheets were already present in the Miocene that drained into the Weddell Sea basin (Fig. 12C). Miocene continental scale ice sheets in Antarctica were also documented in other borehole and seismic reflection data (e.g. Barker et al., 1988; Miller et al., 1990; Zachos et al., 2001; Maldonado et al., 2005, 2006; Leitchenkov et al., 2008; Anderson et al., 2011; Escutia et al., 2011).

Units WS-S6 and WS-S7 were deposited in the Pliocene-Pleistocene (Fig. 3) and have an estimated average thickness of $158 \mathrm{~m}$ and $165 \mathrm{~m}$, respectively across the Weddell Sea basin (Fig. 7; online Supplements 4 and 5). Even though these units are ascribed to the same glacial driven depositional processes as the on average $542 \mathrm{~m}$ thick WS-S5 unit below, they appear much thinner (Fig. 6B). One possibility could be that the initial full glacial ice sheet advancements and retreats already eroded most of the terrigenous and shelf sediments, which were created by the river systems and other erosional processes in the pre-glacial and transitional regimes. Hence resulting in lower sediment supply due to established ice sheets and bedrock erosion and smaller interglacial cycles (Fig. 12D).

\section{Conclusions}

The interpretation of the deep-sea sedimentary record along the $\sim 3300 \mathrm{~km}$ WS-SS seismic transect contribute to our understanding of the Cretaceous to Quaternary evolution of the Antarctic ice sheets in the Weddell Sea basin. The main contributions are summarised in the following conclusions:

1. We developed a new seismic horizon stratigraphy for the Weddell Sea and southern Scotia Sea using boundary conditions from various datasets. Lower units (WS-S1, WS-S2, WS-S3 and WS-S4) were newly interpreted or re-interpreted. The upper 3 units (WS-S5, WS-S6 and WS-S7) are consistent with local scale studies.

2. The pre-glacial (WS-u1 to WS-u4), transitional (WS-u4 to WS-u5) and full glacial (WS-u5 to seafloor) boundary horizons were identified in the Weddell Sea basin and traced into the Jane and Powell Basins and southern Scotia Sea. The proposed seismic unit divisions are consistent with localized seismic stratigraphy studies around Antarctica in the Bellingshausen Sea (e.g. Scheuer et al., 2006), Wilkes Land (e.g. Escutia et al., 2011) East Antarctica (Leitchenkov et al., 2007), Scotia Sea and Antarctic Peninsula basins (Maldonado et al., 2006) and Weddell Sea (Miller et al., 1990), but disagrees with the stratigraphy of Rogenhagen et al. (2004). 
3. Average values for the complete pre-glacial sequence in the Weddell Sea (excluding Jane and Powell Basins): sediment thickness = $1100 \mathrm{~m}$, sedimentation rate $=2.7 \mathrm{~cm} / \mathrm{ky}$, volume $=1.3 \times 10^{6} \mathrm{~km}^{2}$; the transitional sequence: sediment thickness $=530 \mathrm{~m}$, sedimentation rate $=6.4 \mathrm{~cm} / \mathrm{ky}$, volume $=0.7 \times 10^{6} \mathrm{~km}^{3}$ and; the complete full glacial sequence: sediment thickness $=880 \mathrm{~m}$, sedimentation rate $=5.5 \mathrm{~cm} / \mathrm{ky}$, volume $=1.1 \times 10^{6} \mathrm{~km}^{3}$.

4. In the pre-glacial sequence (WS-S1, WS-S2 and WS-S3), a deposition mound-and-eroded-flank basin geometry lateral variation in sediment thickness, and sedimentation rates calculated from published interval velocity data support a Cretaceous proto-Weddell Gyre hypothesis. A deeper depression on the east of the mound, ascribed to higher erosion hints at a probable clockwise circulation, but in the absence of clear drift structures an anti-clockwise circulation cannot be excluded.

5. The transitional unit (WS-S4 or T-1) is interpreted to represent high sediment supply through accelerated down-slope mass sediment transport deposits such as turbidites, considered indicative of advancing ice sheets grounding on the outer shelf. The crossbasin occurrence and lateral age variation of this unit $(\sim 27 \mathrm{Ma}$ in the southeastern Weddell Sea to $\sim 11 \mathrm{Ma}$ in the northwest) imply initial Oligocene grounding of the WAIS and initial early Miocene grounding of the APIS.

6. In the full glacial sequence, the up to $975 \mathrm{~m}$ thick WS-S5 unit is continuous and fills the depressions on either side of the moundand-eroded-flank topography of the pre-glacial and transitional regimes. WS-S5 represents increased deep-sea sediment deposition due to amplified downslope sediment supply in response to advancing ice sheets permanently grounding on the outer shelf. The lateral continuity and age of this unit ( 18-6 Ma from southeast to northwest) implies concurrent advancement and grounding of the EAIS, WAIS and APIS during the late to early Miocene.

7. The even distribution of the full glacial sequence along the transect suggests that early ice sheet/ice caps/glaciers must have transported sediments not only from the Ronne-Filchner outflow system but also from the Antarctic Peninsula. This is consistent with Smith and Anderson (2010) and implies expansion of the southern APIS to the outer shelf, earlier than the Pleistocene predicted in palaeoclimate models (e.g. Pollard and DeConto, 2009).

8. The younger glacial units WS-S6 and WS-S7 reflect decreased sediment supply to the basin, which is consistent with a reduction in sediment supply following the establishment of a polar glacial regime.

Our Weddell Sea basin seismic stratigraphy rests on the assumption that changes in the observed seismic pattern represent preglacial, transitional and full glacial sequences. The presented age model has been derived from all available age information, geophysical and stratigraphic data. The greatest uncertainties lie in the velocity model and estimated horizon ages. Even so, we consider these results a best estimate for deriving a working hypothesis although the lateral horizon ages within the sedimentary column are only constrained by secondary information. The identification of pre-glacial to glacial components in the deep-sea sediment archive enabled an initial quantification of sediment volumes and thicknesses and rates, which are useful to constrain future palaeobathymetry and palaeotopography reconstructions.

Supplementary data to this article can be found online at http:// dx.doi.org/10.1016/j.margeo.2012.11.004.

\section{Acknowledgements}

YMM and AM thank the "Ministerio de Ciencia e Innovación" of Spain for support through the FPI programme and CGL2004-05646/ ANT, CTM2008-06386-C02/ANT and CTM2011-30241-CO2-01 projects. The study benefited greatly from a three-month research visit of YMM to the Alfred Wegener Institute. We thank M. Rebesco and J. Anderson for their thorough evaluation and reviews of this paper. Colleagues J. Grützner, C. Läderach, M. Mieth and G. Uenzelmann-Neben are sincerely thanked for fruitful discussions that improved the manuscript significantly. This project has been funded through the Priority Program 1158 'Antarctic Research' of the Deutsche Forschungsgemeinschaft under project number GO 724/10-1 (AL and KG) and contributes to the Circum-Antarctic Stratigraphy and Palaeobathymetry project (CASP), a Scientific Committee on Antarctic Research - Antarctic Climate Evolution (SCAR-ACE) working group. In memory to Peter Barker who passed away this year (25.06.2012), for his contributions as Principal Investigator on RRS Discovery Cruise 154 which collected line BAS845-15 line, the critical link in the WS-SS transect, and as Co-Chief Scientist on ODP Leg 113, which provided most of the available age control.

\section{References}

Amante, C., Eakins, B.W., 2009. ETOPO1 1 Arc-Minute Global Relief Model: Procedures, Data Sources and Analysis. NOAA Technical Memorandum NESDIS NGDC-24. (19 pp.).

Anderson, J.B., 1999. Antarctic Marine Geology. Cambridge University Press, Cambridge, (289 pp.)

Anderson, J.B. (Ed.), 2006. SHALDRIL II Cruise Report (http://shaldril.rice.edu/, 369 pp.).

Anderson, J.B., Wellner, J.S. (Eds.), 2011. Tectonic, Climatic, and Cryospheric Evolution of the Antarctic Peninsula. Geopress, American Geophysical Union, Washington DC, USA. http://dx.doi.org/10.1029/SP063 (218 pp.).

Anderson, J.B., Warny, S., Askin, R., Wellner, J., Bohaty, S., Smith, T., 2011. Cenozoic cryosphere expansion and the demise of Antarctica's last refugium. Proceedings of the National Academy of Science 108, 11299-11726.

Barker, P.F., 2001. Scotia Sea regional tectonic evolution: implications for mantle flow and palaeocirculation. Earth-Science Reviews 55, 1-39.

Barker, P.F., Thomas, E., 2004. Origin, signature and palaeoclimate influence of the Antarctic Circumpolar Current. Earth-Science Reviews 55, 1-39. http://dx.doi.org/ 10.1016/j.earscirev.2003.10.003.

Barker, P.F., Kennett, J.P., et al., 1988. Proceedings of the Ocean Drilling Program, Scientific Results Leg 113. Ocean Drilling Program, College Station, TX. http://dx.doi.org/ 10.2973/odp.proc.ir.113.1988. (774 pp.).

Barker, P.F., Dalziel, I.W.D., Storey, B.C., 1991. Tectonic development of the Scotia Arc region. Tingey, R.J. ŽEd., Geology of Antarctica. Oxford Univ. Press, Oxford, In: pp. 215-248.

Bart, P.., De Batist, M., Jokat, W., 1999. Interglacial collapse of Crary trough-mouth Fan, Weddell Sea, Antarctica: implications for Antarctic glacial history. Journal of Sedimentary Research 69 (6), 1276-1289. http://dx.doi.org/10.1306/D4268B5D-2B2611D7-8648000102C1865D.

Bart, P.J., Egan, D., Warny, S.A., 2005. Direct constraints on Antarctic Peninsula Ice Sheet grounding events between 5.12 and $7.94 \mathrm{Ma}$. Journal of Geophysical Research 110, F04008. http://dx.doi.org/10.1029/2004JF000254.

BAS, 1985. Tectonic map of Scotia Arc, sheet 3, scale 1:3,000,000. British Antarctic Survey, Cambridge.

Bentley, M.J., Fogwill, C.J., Le Brocq, A.M., Hubbard, A.L., Sugden, D.E., Dunai, T.J., Freeman, S.P.H.T., 2010. Deglacial history of the West Antarctic Ice Sheet in the Weddell Sea embayment: constraints on past ice volume change. Geology 38 (5), 411-414.

Berner, R.A., Kothavala, Z., 2001. GEOCARB III: A revised model of atmospheric CO2 over Phanerozoic time. American Journal of Science 304, 397-437.

Bohaty, S.M., Kulhanek, D.K., Wise Jr., S.W., Jemison, K., Warny, S., Sjunneskog, C., 2011. Age Assessment of Eocene-Pliocene Drill Cores Recovered During the SHALDRIL II Expedition, Antarctic Peninsula. In: Anderson, J.B., Wellner, J.S. (Eds.), Tectonic, Climatic, and Cryospheric Evolution of the Antarctic Peninsula. Special Publication, 63. American Geophysical Union, pp. 63-113. http://dx.doi.org/10.1029/ 2010 SP001049.

Bohoyo, F., 2004. Fragmentación continental y desarrollo de cuencas oceánicas en el sector meridional del Arco de Scotia, Antártida. Ph. D Thesis, University of Granada, Granada, 252 pp.

Bohoyo, F., Galíndo-Zaldívar, J., Maldonado, A., Schreider, A.A., Suriñach, E., 2002. Basin development subsequent to ridge-trench collision: the Jane Basin, Antarctica. Marine Geophysical Research 23, 413-421. http://dx.doi.org/10.1023/B:MARI. 0000018194.18098.0d.

Bohoyo, F., Galindo-Zaldívar, J., Jabaloy, A., Maldonado, A., Rodríguez-Fernández, J. Schreider, A., Suriñach, E., 2007. Extensional deformation and development of deep basins associated with the sinistral transcurrent fault zone of the Scotia-Antarctic plate boundary. Geological Society, London, Special Publications 290, 203-217. http://dx doi.org/10.1144/SP290.6.

Boyden, J., Müller, R., Gurnis, M., Torsvik, T., Clark, J., Turner, M., Ivey-Law, H., Watson, R., Cannon, J., 2011. Next-generation plate-tectonic reconstructions using GPlates. In: Keller, G., Baru, C. (Eds.), Geoinformatics: Cyber infrastructure for the Solid Earth Sciences. Cambridge University Press, pp. 95-114.

Brown, B., Gaina, C., Müller, R.D., 2006. Circum-Antarctic palaeobathymetry. Palaeogeography, Palaeoclimatology, Palaeoecology 231, 158-168. http://dx.doi.org/ 10.1016/j.palaeo.2005.07.033. 
Busetti, M., Zanolla, C., Marchetti, A., 2000. Geological structure of the South Orkney microcontinent. Terra Antartica 8 (2), 71-78.

Cande, S.C., Kent, D.V., 1995. Revised calibration of the geomagnetic polarity timescale for the Late Cretaceous and Cenozoic. Journal of Geophysical Research 100 (B4), 6093-6095.

Coren, F., Geccone, G., Lodolo, E., Zanolla, C., Zitellini, N., Bonazzi, C., Centonze, J., 1997. Morphology, seismic structure and tectonic development of the Powell Basin, Antarctica. Journal of the Geological Society 154, 849-862.

Coxall, H.K., Wilson, P.A., P"alike, H., Lear, C.H., Backman, J., 2005. Rapid stepwise onset of Antarctic glaciation and deeper calcite compensation in the Pacific Ocean. Nature 433, 53-57. http://dx.doi.org/10.1038/nature03135.

Davies, B.J., Hambrey, M.J., Smellie, J.L., Crrivick, J.L., Glasser, N.F., 2012. Antarctic Peninsula ice sheet evolution during the Cenozoic era. Quaternary Science Reviews 31, 30-66. http://dx.doi.org/10.1016/j.quascirev.2011.10.012.

DeConto, R.M., Pollard, D., 2003. Rapid Cenozoic glaciation of Antarctica induced by declining atmospheric $\mathrm{CO}_{2}$. Nature 421, 245-249. http://dx.doi.org/10.1038/nature01290.

DeSantis, L., Brancolini, G., Donda, F., 2003. Seismo-stratigraphic analysis of the Wilkes Land continental margin (East Antarctica): influence of glacially driven processes on the Cenozoic deposition. Deep Sea Research Part II: Topical Studies in Oceanography 50 (8-9), 1563-1594. http://dx.doi.org/10.1016/S0967-0645(03)00079-1.

Diester-Haass, L., Robert, C., Charnley, H., 1996. The Eocene-Oligocene preglacial-glacial transition in the Atlantic sector of the Southern Ocean (ODP Site 690). Marine Geology 31, 123-149 (SSDI 0025-3227 (95)00174-3).

Dingle, R.V., Lavelle, M., 1998. Late Cretaceous-Cenozoic climatic variations of the northern Antarctic Peninsula: new geo-chemical evidence and review. Palaeogeography, Palaeoclimatology, Palaeoecology 141, 215-232. http://dx.doi.org/10.1016/S00310182(98)00056-X

Diviacco, P., Rebesco, M., Camerlenghi, A., 2006. Late Pliocene mega debris flow deposit and related fluid escapes identified on the Antarctic Peninsula continental margin by seismic reflection data analysis. Marine Geophysical Research 27 (2), 109-128. http://dx.doi.org/10.1007/s11001-005-3136-8.

Eagles, G., 2010. The age and origin of the central Scotia Sea. Geophysical Journal International 183 (2), 587-600. http://dx.doi.org/10.1111/j.1365-246X.2010.04781.x.

Eagles, G., Livermore, R.A., 2002. Opening history of Powell Basin, Antarctic Peninsula. Marine Geology 195-205. http://dx.doi.org/10.1016/S0025-3227(02)00191-3.

Eagles, G., Livermore, R.A., Fairhead, J.D., Morris, P., 2005. Tectonic evolution of the west Scotia Sea. Journal of Geophysical Research 110, B02401. http://dx.doi.org/ 10.1029/JB2004003154.

Eagles, G., Livermore, R.A., Morris, P., 2006. Small basins in the Scotia Sea: the Eocene Drake Passage gateway. Earth and Planetary Science Letters 242, 343-353. http:// dx.doi.org/10.1016/j.epsl.2005.11.060.

Escutia, C., Brinkhuis, H., Klaus, A., the Expedition 318 Scientists, 2011. Proceedings IODP leg 318. Integrated Ocean Drilling Program Management International, Inc., Tokyo. http://dx.doi.org/10.2204/iodp.proc.318.2011.

Ferris, J.K., Vaughan, A.P.M., Storey, B.C., 2000. Relics of acomplex triple junction in the Weddell Sea embayment, Antarctica. Earth and Planetary Science Letters 178, 215-230.

Galindo-Zaldívar, J., Bohoyo, F., Maldonado, A., Schreider, A., Surinãch, E., Vázquez, J.T., 2006. Propagating rift during the opening of a small oceanic basin: the Protector Basin (Scotia Arc, Antarctica). Earth and Planetary Science Letters 241, 398-412. http://dx.doi.org/10.1016/j.epsl.2005.11.056

Gersonde, R., Burckle, L.H., 1990. Neogene diatom biostratigraphy of ODP Leg 113 , Weddell Sea (Antarctic Ocean). In: Barker, P.F., Kennett, J.P. (Eds.), Proceedings of the Ocean Drilling Program Science Results, pp. 761-789. College Station, TX.

Ghidella, M., La Brecque, J., 1997. The Jurassic conjugate margins of the Weddell Sea: considerations based on magnetic, gravity and paleobathymetry data. In: Ricci, C. (Ed.), The Antarctic region: Geological Evolution and Processes. Terra Antarctica Publication, pp. 441-451.

Ghidella, M.E., Yáñez, G., LaBrecque, J.L., 2002. Revised tectonic implications for the magnetic anomalies of the western Weddell Sea. Tectonophysics 347, 65-86. http://dx.doi.org/10.1016/S0040-1951(01)00238-4.

Gradstein, F.M., Agterberg, F.P., Ogg, J.G., Hardenbol, J., van Veen, P., Thierry, T., Huang, Z., 1994. A Mesozoic time scale. Journal of Geophysical Research 99 (B12), 24051-24074.

Gradstein, F.M., Ogg, J.G., Smith, A.G., Bleeker, W., Lourens, L.J., 2004. A new Geologic Time Scale, with special reference to Precambrian and Neogene. Episodes 27, 83-100.

Haq, B.U., Schutter, S.R., 2008. A chronology of Paleozoic sea-level changes. Science 322 (5898), 64-68. http://dx.doi.org/10.1126/science.1161648.

Hayes, D.E., La Brecque, J.L., 1991. Sediment isopachs: circum-Antarctic to $30^{\circ} \mathrm{S}$. In: Hayes, D.E. (Ed.), Marine Geological and Geophysical Atlas of the CircumAntarctic to $30^{\circ} \mathrm{S}$. Antarctic Research Series, 54. American Geophysical Union, Washington, D. C., pp. 29-35.

Hayes, D.E., Zhang, C., Weissel, R.A., 2009. Modeling Paleobathymetry in the Southern Ocean. EOS, Transactions of the American Geophysical Union 90 (19), 165-172.

Hinz, K., 1981. A hypothesis of terrestrial catastrophes - Wedges of verythick oceanward dipping layers beneath passive continental margins - Their origin and paleoenvironmental significance. Geologisches Jahrbuch. E22, 3-28.

Hinz, K., Krause, W., 1982. The continental margin of Queen Maud Land/Antarctica: seismic sequences, structural elements and geological development. Geologisches Jahrbuch E23, 17-41.

Hinz, K., Kristoffersen, Y., 1987. Antarctica, recent advances in the understanding of the continental shelf. Geologisches Jahrbuch E37, 3-54.

Hunter, R.J., Johnson, A.C., Aleshkova, N.D., 1996. Aeromagnetic data from the southern Weddell Sea embayment and adjacent areas: Synthesis and interpretation. In: Storey,
B.C., King, E.C., Livermore, R.A. (Eds.), Weddell Sea Tectonics and GondwanaBreak up: Geological Society Special Publication, 108, pp. 143-154 (London).

Jamieson, S.S.R., Sugden, D.E., Hulton, N.R.J., 2010. The evolution of the subglacial landscape of Antarctica. Earth and Planetary Science Letters 293, 1-27. http://dx.doi.org/ 10.1016/j.epsl.2010.02.012.

Jokat, W., Hübscher, C., Meyer, U., Oszko, L., Schöne, T., Versteeg, W., Miller, H., 1996. The continental margin off East Antarctica between $10^{\circ} \mathrm{W}$ and $30^{\circ} \mathrm{W}$. In: Storey, B. King, E.C., Livermore, R.A. (Eds.), Weddell Sea Tectonics and Gondwana Break-up: Geological Society Special Publication, 108, pp. 129-141 (London).

Jokat, W., Boebel, T., König, M., Meyer, U., 2003. Timing and geometry of early Gondwana breakup. Journal of Geophysical Research 108 (B9), 2428. http://dx.doi.org/10.1029/ 2002JB001802.

Kent, D.V., Gradstein, F.M., 1986. A Jurassic to recent chronology. In: Vogt, P.R. Tucholke, B.E. (Eds.), The Geology of North America, Volume M. The Western North Atlantic Region, Geological Society of America.

Kennett, J.P., Houtz, R.E., Andrews, P.B., Edwards, A.R., Gostin, V.A., Hajos, M. Hampton, M., Jenkins, D.G., Margolis, S.V., Ovenshine, A.T., Perch-Nielsen, K. 1975. Cenozoic paleoceanography in the southwest Pacific Ocean, Antarctic glaciation, and the development of the circum-Antarctic current. In: Kennett, J.P., Houtz, R.E. (Eds.), Initial Report DSDP 29. US Government Printing Office, Washington, pp. 1155-1169.

König, M., Jokat, W., 2006. The Mesozoic breakup of the Weddell Sea. Journal of Geophysical Research 111 (B12102). http://dx.doi.org/10.1029/2005JB004035.

Kovacs, L.C., Morris, P., Brozena, J., Tikku, A., 2002. Seafloor spreading in the Weddell Seas from magnetic and gravity data. Tectonophysics 347, 43-64. http://dx.doi.org/ 10.1016/S0040-1951(01)00237-2.

Kristoffersen, Y., Haugland, K., 1986. Geophysical evidence for East Antarctic plate boundary in the Weddell Sea. Nature 322, 538-541. http://dx.doi.org/10.1038/322538a0.

Kuvaas, B., Kristoffersen, Y., 1991. The Crary Fan: a trough-mouth fan on the Weddel Sea Continental Margin, Antarctica. Marine Geology 97, 345-362.

LaBrecque, J.L., Ghidella, M.E., 1997. Bathymetry, depth to magnetic basement, and sediment thickness estimates from aerogeophysical data over the western Weddel Sea. Journal of Geophysical Research 102, 7929-7945. http://dx.doi.org/10.1029/ 96JB01264.

LaBrecque, J.L., Cande, S., Bell, R., Raymond, C., Brozena, J., Keller, M., Parra, J.C., Yáñez, G., 1986. Aerogeophysical survey yields new data in the Weddell Sea. Antarctic Journal Review 21, 69-71.

Larter, R.D., Barker, P.F., 1989. Seismic stratigraphy of the Antarctic Peninsula Pacific margin: a record of Pliocene-Pleistocene ice volume and paleoclimate. Geology 17 731-734. http://dx.doi.org/10.1130/0091-7613(1989) 017<0731:SSOTAP > 2.3.CO;2.

Larter, R.D., Cunningham, A.P., 1993. The depositional pattern and distribution of glacialinterglacial sequences on the Antarctic Peninsula Pacific margin. Marine Geology 109 203-219. http://dx.doi.org/10.1016/0025-3227(93)90061-Y.

Laske, G., Masters, G., 1997. A global digital map of sediment thickness. EOS, Transactions American Geophysical Union 78 (46), F483 (Fall Meeting Supplement)

Lawver, L.A., Gahagan, L.M., 1998. Opening of Drake Passage and its impact on Cenozoic ocean circulation. In: Crowley, T.J., Burke, K.C. (Eds.), Tectonic Boundary Conditions for Climate Reconstructions. : Oxford Monographs on Geology and Geophysics. Oxford University Press, Oxford, pp. 212-223.

Lawver, L.A., Gahagan, L., 2003. Evolution of Cenozoic Seaways in the circum-Antarctic region. Palaeogeography, Palaeoclimatology, Palaeoecology 198, 11-37. http:// dx.doi.org/10.1016/S0031-0182(03)00392-4.

Le Brocq, A.M., Payne, A.J., Vieli, A., 2010. An improved Antarctic dataset for high resolution numerical ice sheet models (ALBMAP v1). Earth System Science Data Discus sions 3, 195-230. http://dx.doi.org/10.5194/essdd-3-195-2010 (www.earth-systsci-data-discuss.net/3/195/2010/).

Lear, C.H., Bailey, T.R., Pearson, P.N., Coxall, H.K., Rosenthal, Y., 2008. Cooling and ice growth across the Eocene-Oligocene transition. Geology 36, 251-254. http:// dx.doi.org/10.1130/G24584A.1.

Leitchenkov, G.L., Guseva, Y.B., Gandyukhin, V.V., 2007. Cenozoic environmental changes along the East Antarctic continental margin inferred from regional seismic stratigraphy. In: Cooper, A.K., Raymond, C.R. (Eds.), Antarctica: A Keystone in a Changing World-Online Proceedings of the 10th ISAES: USGS Open-File Report 2007-1047, Short Research Paper 005. http://dx.doi.org/10.3133/of2007-1047.srp005.

Leitchenkov, G., Guseva, J., Gandyukhin, V., Grikurov, G., Kristoffersen, Y., Sand, M. Golynsky, A., Aleshkova, N., 2008. Crustal structure and tectonic provinces of the Riiser-Larsen Sea are (East Antarctica): results of Geophysical studies. Marine Geophysical Research 29, 135-158. http://dx.doi.org/10.1007/s11011-008-9051-z.

Lindeque, A., Martos, Y.M., Gohl, K., Maldonado, A., 2012. Seafloor Spreading Magnetic Anomaly Isochron Map Compilation for the Weddell Sea and Scotia Sea. http:// dx.doi.org/10.1594/PANGAEA.777453 . (www.pangea.de).

Livermore, R.A., Hunter, R.J., 1996. Mesozoic seafloor spreading in the southern Weddell Sea. In: Storey, B., King, E.C., Livermore, R.A. (Eds.), Weddell Sea Tectonics and Gondwana Break-up: Geological Society Special Publication, 108, pp. 227-241 (London).

Livermore, R.A., Balanyá, J.C., Maldonado, A., Martínez, J.M., Rodríguez-Fernández, J., Sanz de Galdeano, C., Galindo- Zaldívar, J., Jabaloy, A., Barnolas, A., Somoza, L., Hernández, J., Suriñach, E., Viseras, C., 2000. Autopsy on a dead spreading centre: the Phoenix Ridge, Drake Passage, Antarctica. Geology 18, 607-610. http:// dx.doi.org/10.1130/0091-7613(2000)28<607:AOADSC > 2.0.CO;2.

Livermore, R., Nankivell, A., Eagles, G., Morris, P., 2005. Paleogene opening of Drake Passage. Earth and Planetary Science Letters 236, 459-470. http://dx.doi.org/ 10.1016/j.epsl.2005.03.027.

Livermore, R.A., Hillenbrand, C.-D., Meredith, M., Eagles, G., 2007. Drake Passage and Cenozoic climate: an open and shut case? Geochemistry, Geophysics, Geosystems 8, Q01005. http://dx.doi.org/10.1029/2005GC001224. 
Lodolo, E., Coren, F., Schreider, A.A., Ceccone, G., 1998. Geophysical evidence of a relict oceanic crust in the southwestern Scotia Sea. Marine Geophysical Research 19 439-450. http://dx.doi.org/10.1023/A:1004355707951.

Lodolo, E., Civile, D., Vuan, A., Tassone, A., Geletti, R., 2010. The Scotia-Antarctica plate boundary from $35^{\circ} \mathrm{W}$ to $45^{\circ} \mathrm{W}$. Earth and Planetary Science Letters $293,200-215$. http://dx.doi.org/10.1016/j.epsl.2009.12.045.

Lythe, M.B., Vaughan, G.D., the BEDMAP Consortium, 2001. BEDMAP: a new ice thickness and subglacial topographic model of Antarctica. Journal of Geophysica Research 106, 11335-11351. http://dx.doi.org/10.1029/2000JB900449.

Maldonado, A., Aldaya, F., Balanyá, J.C., Galindo Zaldivar, J., Livermore, R.A., Monseñe F.M., Rodríguez-Fernández, J., Roussanov, M., Sanz de Galdeano, C., Suriñach, E. Viseras, C., 1993. Tectonics and paleoceanography in the northern sector of the Antarctic Peninsula: preliminary results of HESANT1992/93 cruise with the B/O HESPERIDES. Scientia Marina 57 (1), 79-89.

Maldonado, A., Zitellini, N., Leitchenkov, G., Balanyá, J.C. Coren, F., Galindo-Zaldívar, J. Lodolo, E., Jabaloy, A., Zanolla, C., Rodríguez-Fernández, J., Vinnikovskaya, O., 1998. Small ocean basin development along the Scotia-Antarctica plate boundary and in the northern Weddell Sea. Tectonophysics 296, 371-402.

Maldonado, A., Balanyá, J.C., Barnolas, A., Galindo-Zaldívar, J., Hernández, J., Jabaloy, A Livermore, R., Martínez-Martínez, J.M., Rodríguez-Fernández, J., Sanz de Galdeano C., Somoza, L., Suriñach, E., Viseras, C., 2000. Tectonics of an extinct ridge-transform intersection, Drake Passage (Antarctica). Marine Geophysical Research 21, 43-68. http://dx.doi.org/10.1023/A:1004762311398

Maldonado, A., Barnolas, A., Bohoyo, F., Galindo-Zaldívar, J., Hernández-Molina, J., Lobo, F., Rodríguez-Fernández, J., Somoza, L., Vázquez, J.T., 2003. Contourite deposits in the central Scotia Sea: the importance of the Antarctic Circumpolar Current and Weddell Gyre flows. Palaeogeography, Palaeoclimatology, Palaeoecology 198, 187-221. http:// dx.doi.org/10.1016/S0031-0182(03)00401-2.

Maldonado, A., Barnolas, A., Bohoyo, F., Escutia, C., Galindo-Zaldívar, J., Hernández Molina, F.J., Jabaloy, A., Lobo, F.J., Nelson, C.H., Rodríguez-Fernández, J., Somoza, L, Vázquez, J.T., 2005. Miocene to recent contourite drifts development in the northern Weddell Sea (Antarctica). Global Planet Change 45, 99-129.

Maldonado, A., Bohoyo, F., Galindo-Zaldívar, J., Hernández-Molina, F.J., Jabaloy, A., Lobo F.J., Rodríguez-Fernández, J., Suriñach, E., Vázquez, J.T., 2006. Ocean basins near the Scotia-Antarctic plate boundary: influence of tectonics and paleoceanography on the Cenozoic deposits. Marine Geophysical Research 27, 83-107. http://dx.doi.org/ 10.1007/s11001-006-9003-4.

Maldonado, A., Bohoyo, F., Galindo-Zaldívar, J., Hernández-Molina, F.J., Lobo, F.J., Shreyder, A.A., Suriñach, E., 2007. Early opening of Drake Passage: regional seismic stratigraphy and paleoceanographic implications, in Antarctica: A Keystone in a Changing World. Extended Abstract EA57, online Proceedings of the 10th International Symposium on Antarctic Sciences (ISAES). In: Cooper, A.K., Raymond, C.R., et al. (Eds.), USGS Open-File Report (http://pubs.usgs.gov/of/2007/1047/ea/of20071047ea057.pdf).

Michels, K.H., Rogenhagen, J., Kuhn, G., 2001. Recognition of contour-current influence in mixed contourite-turbidite sequences of the western Weddell Sea, Antarctica. Marine Geophysical Research 22, 465-485. http://dx.doi.org/10.1023/A:1016303817273.

Michels, K.H., Kuhn, G., Hillenbrand, C.-D., Diekmann, B., Fütterer, D.K., Grobe, H., Uenzelmann-Neben, G., 2002. The southern Weddell Sea: combined contouriteturbidite sedimentation at the southeastern margin of the Weddell Gyre. In: Stow, D.A.V., Pudsey, C., Howe, J.C., Faugères, J.-C., Viana, A.R. (Eds.), Geological Society of London, Memoirs, 22, pp. 305-323. http://dx.doi.org/10.1144/GSL.MEM. 2002.022.01.32

Miller, H., Henriet, J.P., Kaul, N., Moons, A., 1990. A fine-scale stratigraphy of the eastern margin of the Weddell Sea. In: Bleil, U., Thiede, J. (Eds.), Geological History of the Polar Oceans: Arctic Versus Antarctic. Kluwer Academic Publishers, pp. 131-161.

Miller, K.G. Wright, J.D., Katz, M.E., Browning J.V., Cramer, B.S., Wade, B.S., Mizintseva, S.F. 2008. A view of Antarctic ice-sheet evolution from sea-level and deep-sea isotope changes during the Late Cretaceous-Cenozoic. In: Cooper, A.K., Barrett, P.J., Stagg, H., Storey, B., Stump, E., Wise, W., the 10th ISAES editorial team (Eds.), Proceedings of the 10th International Symposium on Antarctic Earth Sciences. The National Academies Press, Washington, DC. http://dx.doi.org/10.3133/of2007-1047.kp06.

Nankivell, A.P., 1997. Tectonic evolution of the Southern Ocean. PhD thesis, Oxford University.

Oszko, L., 1997. Tectonic structures and glaciomarine sedimentation in the South-Eastern Weddell Sea from seismic reflection data. Berichte zur Polarforschung (Reports on Polar Research), 222. Alfred Wegener Institut für Polar und Meeresforschung, Bremerhaven, Germany. PhD thesis, University of Bremen. hdl:10013/epic.12931.

Pagani, M., Zachos, J., Freeman, K.H., Tipple, B., Bohaty, S., 2005. Marked decline in atmospheric carbon dioxide concentrations during the Paleogene. Science 309 (5734), 600-603. http://dx.doi.org/10.1126/science.1110063.

Pollard, D., DeConto, R.M., 2009. Modelling West Antarctic ice sheet growth and collapse through the past five million years. Nature 458, 320-323. http://dx.doi.org/ 10.1038 /nature07809.
Pritchard, H.D., Arthern, R.J., Vaughan, D.G., Edwards, 2009. Extensive dynamic thinning on the margins of the Greenland and Antarctic ice sheets. Nature 461, 971-975. http://dx.doi.org/10.1038/nature08471.

Ramsay, A.T.S., Baldauf, J.G., 1990. A reassessment of the Southern Ocean biochronology. Memoirs of the Geological Society of America 18, 1-122.

Rebesco, M., Camerlenghi, A., 2008. Late Pliocene margin development and mega debris flow deposits on the Antarctic continental margins: evidence of the onset of the modern Antarctic Ice Sheet? Palaeogeography, Palaeoclimatology, Palaeoecology 260, 149-167.

Rebesco, M., Camerlenghi, A., Geletti, R., Canals, M., 2006. Margin architecture reveals the transition to the modern Antarctic ice sheet ca. 3 Ma. Geology 34, 301-304. http://dx.doi.org/10.1130/G22000.1.

Rignot, E.J., Bamber, J.L., van den Broeke, M.R., Davis, C., Li, Y., van de Berg, W., van Meijgaard, 2008. Recent Antarctic ice mass loss from radar interferometry and regional climate modelling. Nature Geoscience 1. http://dx.doi.org/10.1038/ngeo102.

Ritzmann, O., 1998. Refraktionsseismische Untersuchungen am Kontinentalrand der Ostantarktis. Diploma thesis (unpublished), Rheinische Friedrich-Wilhelms Universität, Bonn.

Rogenhagen, J., Jokat, W., 2000. The sedimentary structure in the western Weddell Sea. Marine Geology 168, 45-60. http://dx.doi.org/10.1016/S0025-3227(00)00048-7.

Rogenhagen, J., Jokat, W., 2002. Origin of the gravity ridges and Anomaly-T in the southern Weddell Sea. In: Gamble, J.A., Skinner, D.N.B., Henrys, S. (Eds.), Antarctica at the Close of a Millennium, Proceedings of the 8th International Symposium on Antarctic Earth Sciences. Royal Society of New Zealand, Wellington, pp. 227-231.

Rogenhagen, J., Jokat, W., Hinz, K., Kristoffersen, Y., 2004. Improved seismic stratigraphy of the Mesozoic Weddell Sea. Marine Geophysical Researches 25, 265-282. http://dx.doi.org/10.1007/s11001-005-1335-y.

Scher, H.D., Martin, E.E., 2006. Timing and climatic consequences of the opening of Drake Passage. Science 312, 428-430.

Scheuer, C., Gohl, K., Eagles, G., 2006. Gridded isopach maps from the South Pacific and their use in interpreting the sedimentation history of the West Antarctic continental margin. Geochemistry, Geophysics, Geosystems 7, Q11015. http://dx.doi.org/ 10.1029/2006GC001315.

Smith, R.T., Anderson, J.B., 2010. Ice-sheet evolution in James Ross basin, Weddell Sea margin of the Antarctic Peninsula: the seismic stratigraphic record. Geological Society of America Bulletin 122 (5/6), 830-842. http://dx.doi.org/10.1130/B26486.1.

Smith, R.T., Anderson, J.B., 2011. Seismic stratigraphy of the Joinville Plateau: implications for regional climate evolution. In: Anderson, J.B., Wellner, J.S. (Eds.), Tectonic, Climatic, and Cryospheric Evolution of the Antarctic Peninsula. Geopress, American Geophysical Union, Washington DC, USA, pp. 51-61. http://dx.doi.org/10.1029/ 2010 SP000980

Smith, W.H.F., Sandwell, D.T., 1997. Global seafloor topography from satellite altimetry and ship depth soundings. Science 277, 1957-1962.

Surinãch, E., Galindo-Zaldívar, J., Maldonado, A., Livermore, R., 1997. Large amplitude magnetic anomalies in the northern sector of the Powell Basin, NE Antarctic Peninsula. Marine Geophysical Research 19, 65-80. http://dx.doi.org/10.1023/A:1004240931967.

Tripati, A.K., Roberts, C.D., Eagle, R.A., 2009. Coupling of $\mathrm{CO}_{2}$ and ice sheet stability over major climate transitions of the last 20 million years. Science 326, 1394-1397. http://dx.doi.org/10.1016/j.gca.2011.01.018.

Tripati, A.K. Roberts, C.D., Eagle, R.A. Li, G, 2011. A 20 million year record of planktic foraminiferal $\mathrm{B} / \mathrm{Ca}$ ratios: systematics and uncertainties in $\mathrm{pCO}_{2}$ reconstructions. Geochimica et Cosmochimica Acta 75 (10), 2582-2610. http://dx.doi.org/10.1016/ j.gca.2011.01.018

Uenzelmann-Neben, G., 2006. Depositional patterns at Drift 7, Antarctic Peninsula: along- slope versus down-slope sediment transport as indicators for oceanic currents and climatic conditions. Marine Geology 233, 49-62. http://dx.doi.org/ 10.1016/j.margeo.2006.08.008.

Wardell, N., Childs, J.R., Cooper, A.K., 2007. Advances through collaboration: sharing seismic reflection data via the Antarctic Seismic Data Library System for Cooperative Research (SDLS). In: Cooper, A.K., Raymond, C.R. (Eds.), Antarctica: A Keystone in a Changing World-Online Proceedings of the 10th ISAES: USGS Open-File Report 2007-1047, Short Research Paper 001. http://dx.doi.org/10.3133/of20071047.srp001 (4 pp.).

Wilson, D.S., Jamieson, S.S.R., Barrett, PJ. Leitchenkov, G, Gohl, K., Larter, R.D., 2011. Antarctic topography at the Eocene-Oligocene boundary. Palaeogeography, Palaeoclimatology, Palaeoecology. http://dx.doi.org/10.1016/j.palaeo.2011.05.028.

Zachos, J.C., Kump, L.R., 2005. Carbon cycle feedbacks and the initiation of Antarctic glaciation in the earliest Oligocene. Global and Planetary Change 47, 51-66. http://dx.doi.org/10.1016/j.gloplacha.2005.01.001.

Zachos, J., Pagani, M., Sloan, L., Thomas, E., Billups, K., 2001. Trends, rhythms, and aberrations in global climate $65 \mathrm{Ma}$ to present. Science 292/5517, 686-693. http:// dx.doi.org/10.1126/science.1059412. 